FRANCESCO BORDIGNON

\title{
UMA ANÁLISE DA METODOLOGIA DE PRODUÇÃO DE CERÂMICA: COMPARAÇÃO DA PRODUÇÃO DE MONOQUEIMA NA ITÁLIA E NO BRASIL
}

Dissertação apresentada à Escola Politécnica da Universidade de São Paulo para a obtenção do título de Mestre em Engenharia. 
FRANCESCO BORDIGNON

\section{UMA ANÁLISE DA METODOLOGIA DE PRODUÇÃO DE CERÂMICA: COMPARAÇÃO DA PRODUÇÃO DE MONOQUEIMA NA ITÁLIA E NO BRASIL}

Dissertação apresentada à Escola Politécnica da Universidade de São Paulo para a obtenção do título de Mestre em Engenharia.

Área de Concentração:

Engenharia Naval

Orientador:

Prof. Dr. Paulo Carlos Kaminski

São Paulo

2007 
A Sandra, esposa, amiga, companheira, cúmplice, minha vida. 


\section{AGRADECIMENTOS}

O mais profundo agradecimento ao meu orientador, Prof. Dr. Paulo Carlos Kaminski, pelo grande exemplo de seriedade, profissionalismo, honestidade e competência; pela paciência, pelo constante encorajamento, pela ajuda profissional e pela amizade.

Agradecimentos, também, à minha esposa, Sandra, por ter, sempre e incondicionalmente, acreditado em minhas escolhas.

A meu pai, pelo apoio.

Ao Sr. Silvério Maffei, meu amigo e mentor no mundo da cerâmica.

Aos Professores Carlo Palmonari (ad memoriam) e Giorgio Timellini, do Centro Ceramico de Bologna, pela atenção, aconselhamento, ajuda e disponibilidade.

Aos Professores Nilton Nunes Toledo, Marcelo Ramos Martins, Marcelo Massarani, pelas sugestões e pelas críticas.

Ao Prof. Dr. Cláudio Possani, pelo encorajamento e pela amizade.

Ao pessoal da Secretaria de pós-graduação da Naval e da Secretaria automotiva pelo suporte.

A todos aqueles que, direta ou indiretamente, contribuíram para a realização deste trabalho. 


\section{RESUMO}

O presente trabalho se propõe a analisar as marcantes diferenças entre os mercados italiano e brasileiro de cerâmica para revestimento. Desde os anos 60, marco de início da produção industrial moderna de pisos e azulejos, a Itália assumiu a liderança e o Brasil ocupou o terceiro lugar; apenas recentemente a China assumiu a liderança absoluta, como produtor, porém não tem ainda forte expressão como exportador. O estudo visa a melhorar a compreensão das causas geradoras de tais diversidades, a verificar a sua persistência e a estimular uma reflexão dos produtores nacionais a respeito da evidente necessidade de uma profunda reestruturação do setor, buscando recuperar competitividade através da modernização tecnológica e, principalmente, dos sistemas de gestão estratégica. Inicialmente é descrito o que é um produto cerâmico, como é classificado e o estado atual das normas; é fornecida uma imagem geral do mercado mundial, expondo a distribuição de produção e consumo, detalhando as realidades italiana e brasileira, com dados atualizados. Em seguida, é analisado o processo de monoqueima, identificando as diferenças entre os dois países. Finalmente, uma análise das estratégias adotadas identifica as causas históricas da situação atual. Verifica-se a subsistência das motivações que justificam as escolhas tecnológicas, gerando uma lista de recomendações, base para futuras pesquisas sobre a viabilidade de adequar o Brasil, para recuperar competitividade e abrir novos espaços de mercado.

Palavras chave: Cerâmica (Produção). Pisos. Azulejos. Planejamento estratégico. Administração da produção. 


\begin{abstract}
The present work intends to analyze the outstanding differences between the Italian and the Brazilian ceramic tile markets. Since the sixties, "square one" of the modern ceramic tile industrial production, Italy took on the leadership and Brazil the third place; just recently China took on the absolute leadership as a producer, but still do not have strong expression as an exporter. This study aims at improving the comprehension of the causes that generate these differences, verifying their current persistency and stimulating a reflexion by the national producers about the clear need of a deep business field restructuration, searching for competitivity recuperation through technological and, mainly, strategic management system modernization. In the beginning there are a description of a ceramic product, its classification and a survey of the Standards state of the art. A general view of the world market is also supplied, exposing production and sale distribution and detailing the Italian and Brazilian realities, using up-to-date data. Following, the single-firing process is precisely analyzed, identifying the differences between the two countries. Finally, an analysis of the adopted strategies identifies the historical causes of the present situation. It's verified the subsistence of the reasons that support the technological choices, creating a list of observations, base for future researches about the viability to up-date the Brazil ceramic reality, to generate higher competitiveness and open new market spaces.
\end{abstract}

Keywords: Ceramic (Production). Ceramic tiles. Strategic Planning. Production management. 


\section{LISTA DE TABELAS}

Tabela 1 - Classificação de produtos cerâmicos pela Norma ISO 13006 .......... 11

Tabela 2 - Relação entre tipo de produto e classificação da Norma ISO 13006 . 11

Tabela 3 - Classificação de produtos cerâmicos pela Norma ANSI A $137.1 \ldots 12$

Tabela 4 - Classificação dos produtos cerâmicos em função das denominações técnico-comerciais

Tabela 5 - Características técnicas dos produtos cerâmicos conforme a Norma ISO 13006 16

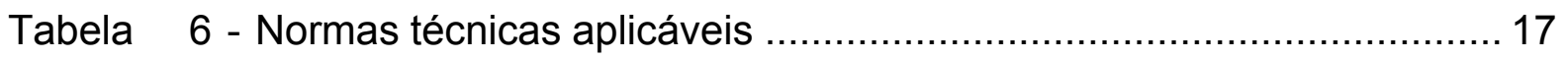

Tabela 7 - Sistemas de certificação ...................................................... 17

Tabela 8 - Produção mundial na década 1990-2000 e em 2001, dividida por áreas geográficas ............................................................ 20

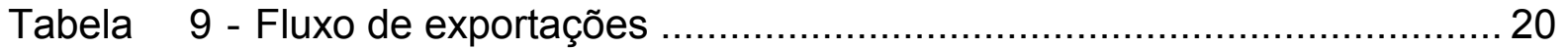

Tabela 10 - Consumo mundial de produtos cerâmicos em 2004 ......................... 22

Tabela 11 - Distribuição da produção italiana por tipologia de produto ................ 23

Tabela 12 - Volume e variação de vendas da produção italiana por destino ........ 24

Tabela 13 - Distribuição da produção brasileira por tipologia de produto .............. 25

Tabela 14 - Mercados de destino das exportações brasileiras ........................... 25

Tabela 15 - Preço unitário dos produtos cerâmicos (US\$ FOB/t) ...................... 30

Tabela 16 - Resumo comparativo dos dados de produção e venda - ano 2004 .. 32

Tabela 17 - Custos totais de fabricação no mercado italiano ............................... 49

Tabela 18 - Composição de custos de produção no mercado italiano ...................50

Tabela 19 - Resumo das características tecnológicas .................................. 51

Tabela 20 - Situação normativa atual .................................................... 52

Tabela 21 - Principais dados de mercado ................................................ 53

Tabela 22 - Principais características tecnológicas ....................................... 54

Tabela 23 - Matriz de presença de atores e áreas de atuação ............................ 59 


\section{LISTA DE FIGURAS}

Figura 1 - Localização dos pólos cerâmicos ........................................... 32

Figura 2 - Fluxograma do processo genérico de produção de monoqueima ...... 36

Figura 3 - Fluxograma do processo de produção de monoqueima na Itália ...... 43

Figura 4 - Fluxograma do processo de produção de monoqueima no Brasil ...... 47 


\section{LISTA DE ABREVIATURAS E SIGLAS}

ABNT

Associação Brasileira de Normas Técnicas

ANFACER

Associação Nacional dos Fabricantes de Cerâmica para

Revestimento

ANSI American National Standard Institute

APL

Arranjo Produtivo Local

ASPACER Associação Paulista das Cerâmicas de Revestimento

ASSOPIASTRELLE Associazione Nazionale dei produttori di piastrelle di ceramica e di materiali refrattari

ASTM

American Society for Testing Materials

EU

European Union

EUA

Estados Unidos da América

FOB

Free On Bord (Incoterms)

IPC

Índice de preços ao consumidor

ISO

International Organization for Standardization

NAFTA

North American Free Trade Agreement

UNI

Ente Nazionale Italiano di Unificazione 


\section{LISTA DE SÍMBOLOS}

$\begin{array}{ll}\mathrm{AA} & \text { absorção de água } \\ \mathrm{a.C} . & \text { antes de Cristo } \\ \mathrm{Cd} & \text { Cádmio (elemento) } \\ \mathrm{cm} & \text { centímetro } \\ { }^{\circ} \mathrm{C} & \text { Grau Célsius } \\ \mathrm{CO}_{2} & \text { dióxido de carbono } \\ \mathrm{g} & \text { grama } \\ \mathrm{GN} & \text { gás natural } \\ \mathrm{Hg} & \text { mercurio (elemento) } \\ \mathrm{kg} & \text { kilograma } \\ \mathrm{m} & \text { metro } \\ \mathrm{Mm} & \text { milhões de metros quadrados } \\ \mathrm{min} & \text { minuto } \\ \mathrm{mm} & \text { milímetro } \\ \mathrm{N} & \text { Newton } \\ \mathrm{Nm} & \text { metro cúbico em condições normais }\left(760 \mathrm{mmHg} \mathrm{e} 15^{\circ} \mathrm{C}\right) \\ \mathrm{Pa} & \text { Pascal } \\ \mathrm{Pb} & \text { Chumbo (elemento) } \\ \mathrm{t} & \text { Dólar dos Estados Unidos } \\ \mathrm{US} \$ & \end{array}$




\section{SUMÁRIO}

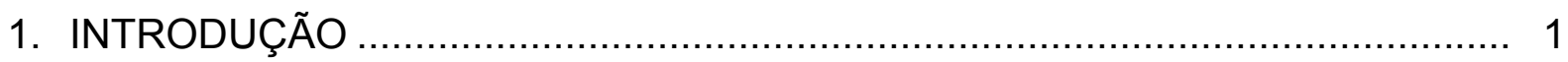

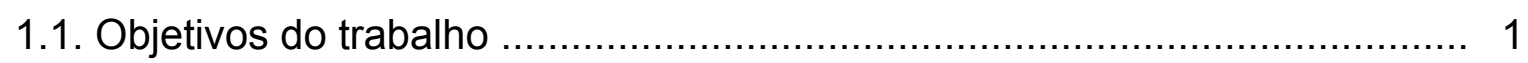

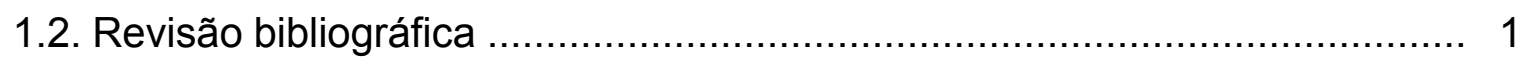

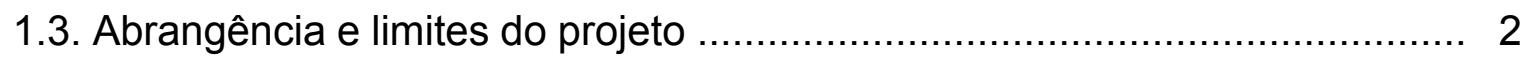

1.4. Estrutura do trabalho .................................................................... 2

1.5. O produto cerâmico ...................................................................... 3

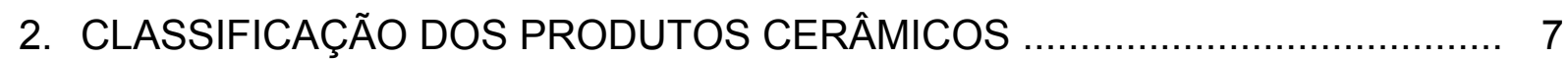

2.1. Normas Aplicáveis ................................................................. 10

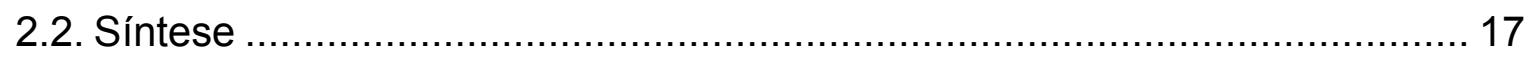

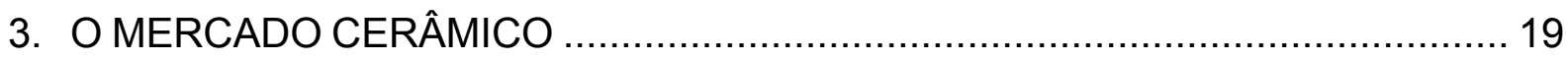

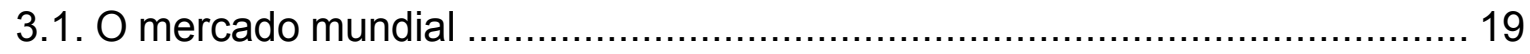

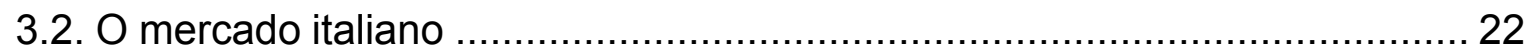

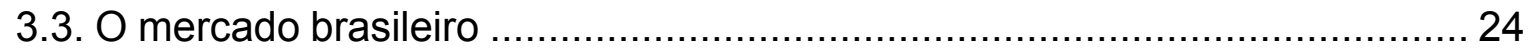

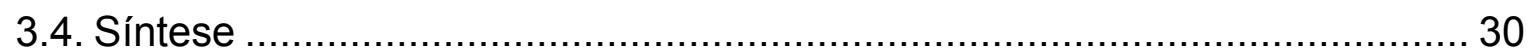

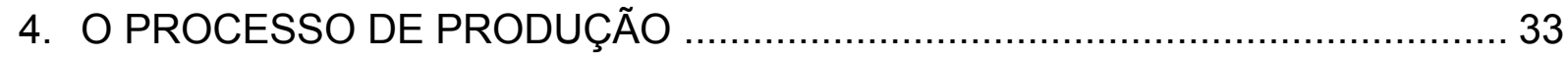

4.1. O processo geral de monoqueima ................................................... 33

4.2. A produção de monoqueima na Itália .............................................. 42

4.3. A produção de monoqueima no Brasil .............................................. 45

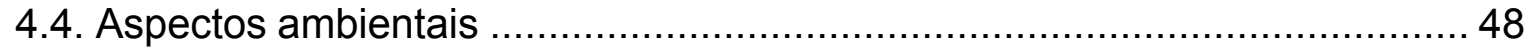

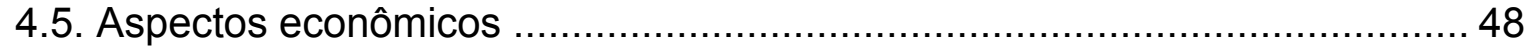

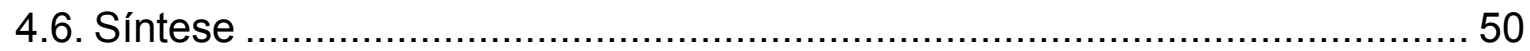

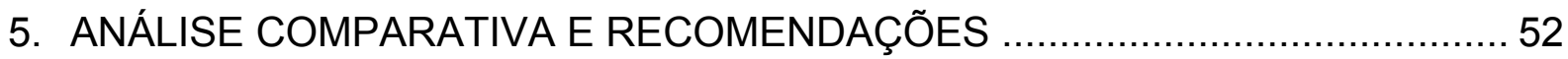

5.1. Análise comparativa ................................................................ 52

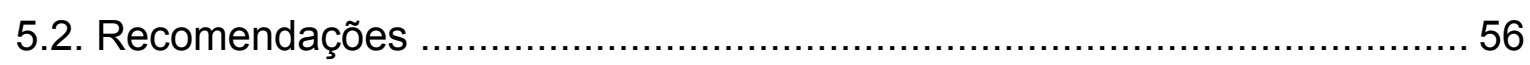

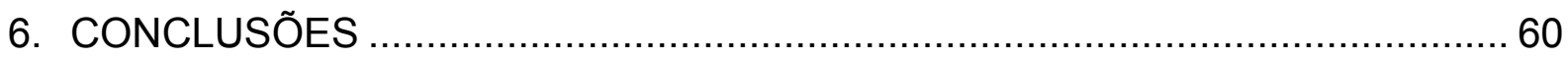

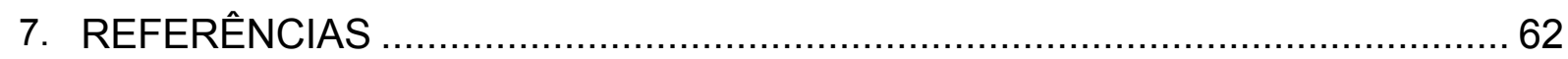




\section{INTRODUÇÃO}

\subsection{Objetivos do trabalho}

A presente dissertação se propõe analisar, de forma ampla e atualizada, o setor de produção de cerâmica para revestimento na Itália e no Brasil. O foco principal do trabalho são os aspectos normativo, de mercado, tecnológico e estratégico. Verificando a existência de grandes diferenças do ponto de vista da tecnologia adotada, da qualidade e da composição do leque de produtos oferecidos, das características do mercado em termo de consumo interno e exportação, de preços praticados, de estratégias de gestão, o objetivo é identificar as causas geradoras das diversidades observadas, procurar verificar, entender e justificar a persistência das motivações, analisar as conseqüências da situação atual sobre mercado e produção e, finalmente, listar uma série de recomendações que podem ser utilizadas para orientar as escolhas estratégicas necessárias à garantia da sobrevivência e da expansão da cerâmica brasileira no mercado mundial.

\subsection{Revisão bibliográfica}

O presente trabalho baseia-se numa ampla bibliografia, resultado de cuidadosa pesquisa; as fontes consultadas compreendem normas técnicas, textos científicos, produção acadêmica (dissertações e monografias), artigos técnicos publicados em jornais e revistas nacionais e internacionais, informações e dados disponibilizados em sites de instituições e organizações nacionais e internacionais. Sempre que possível, a pesquisa bibliográfica foi realizada procurando material atualizado, dando preferência a publicações posteriores ao ano 2000; exceção foi aberta para alguns textos considerados fundamentais e únicos, que - apesar da data de publicação bem anterior ao limite imposto - podem ainda ser considerados atuais. 


\subsection{Abrangência e limites do projeto}

A presente dissertação limita-se à análise dos produtos realizados com 0 processo de monoqueima ${ }^{1}$ que, a partir dos anos setenta, é o mais difundido e representa cerca de $80 \%$ da produção total. Restringe-se também ao Brasil e à Itália, respectivamente $4^{\circ}$ e $2^{\circ}$ produtores no mundo por capacidade. A China, embora hoje o primeiro produtor mundial em quantidade, não é analisada por ser um mercado muito jovem e carente de informações detalhadas e confiáveis a respeito de produção e processos. A Espanha, atualmente $3^{\circ}$ produtor, também não é incluída na presente avaliação, por ser um mercado relativamente jovem, com uma produção mais específica e direcionada para a fabricação de monoporosa ${ }^{2}$, e por utilizar uma tecnologia similar à italiana.

\subsection{Estruturação do trabalho}

O trabalho apresenta-se dividido em sete capítulos.

No primeiro capítulo, são declarados os objetivos da dissertação, indicando os limites de abrangência da pesquisa e apresentando, brevemente, a estrutura do trabalho. Finalmente é fornecida uma rápida descrição do produto cerâmico, focando as tipologias aqui discutidas e reportando as definições disponíveis na literatura pesquisada, procurando fornecer algumas noções básicas para o leitor.

No segundo capítulo, é apresentada a classificação dos produtos cerâmicos conforme as denominações comerciais mais utilizadas e as normas específicas do setor, hoje amplamente difundidas, constituindo referência obrigatória para os produtores que queiram ter acesso aos mercados mundiais. Neste contexto, as normas são examinadas por blocos econômicos, considerando-se a Europa (normas ISO), a América do Norte (ANSI-ASTM) e a América do Sul, com particular foco no Brasil (ABNT).

\footnotetext{
${ }^{1}$ Monoqueima: processo de produção que prevê uma única passagem no forno de queima.

${ }^{2}$ Monoporosa: peças cerâmicas de monoqueima com níveis de porosidade e absorção de água maiores que a monoqueima tradicional. (Centro Ceramico di Bologna, 1999).
} 
O terceiro capítulo apresenta uma análise atualizada dos mercados cerâmicos, avaliando a situação mundial em geral e, mais especificamente, os dois mercados de interesse: o italiano e o brasileiro.

O quarto capítulo descreve o processo de produção de peças cerâmicas para revestimento, com enfoque principal sobre o processo chamado de "monoqueima", hoje o mais difundido. Neste contexto são avaliados os princípios tecnológicos gerais do processo e as particularidades que diferenciam a realidade italiana da brasileira. São analisados, também, os aspectos econômicos e ambientais que mais influenciam os mercados analisados.

O quinto capítulo é um compêndio das comparações das principais normas técnicas do setor, informações de mercado, de processo e estratégias, destacando os fatores e parâmetros julgados mais significativos. É também gerada uma lista de recomendações que visam a chamar a atenção dos produtores brasileiros sobre os aspectos mais delicados do setor, podendo servir-lhes de guia na tomada de decisões estratégicas.

O sexto capítulo traz as considerações finais sobre a diferenciação entre a Itália e - Brasil e sugere novos trabalhos para expansão e aprofundamento das problemáticas aqui tratadas.

O sétimo e conclusivo capítulo lista as referências bibliográficas que foram utilizadas para o desenvolvimento da presente dissertação.

\subsection{O produto cerâmico}

A cerâmica é um dos manufaturados mais antigos: pense-se nas estátuas ou nos vasos de barro, testemunhas de civilizações remotas. É também um dos materiais mais modernos e avançados: composições cerâmicas especiais encontram aplicação cada vez mais difundida nas indústrias eletrônica, mecânica, nuclear, química, etc. (PALMONARI; TIMELLINI, 2000a).

Material cerâmico é qualquer produto, de forma definida, composto de matérias primas inorgânicas, não metálicas (minerais ou artificiais), que de um estado de pó é transformado em semimanufaturado e, por queima, passa a ser sólido com estrutura parcialmente cristalina e parcialmente vidrosa (VECCHI, 1977). 
As peças cerâmicas são materiais sintéticos, obtidos a partir da combinação de matéria primas naturais, para fabricar produtos com características predefinidas (SACMI, 2003). Pisos e azulejos são chapas relativamente finas e de vários formatos de material cerâmico, utilizados para revestir pisos e paredes.

O termo "cerâmico" define a natureza do material constituinte e aplica-se tradicionalmente a produtos obtidos a partir de massas de argilas, areia e outras substâncias naturais. Tais massas, após adequada preparação, são conformadas nas dimensões desejadas e queimadas a elevada temperatura $\left(1.000-1.250^{\circ} \mathrm{C}\right.$, dependendo do tipo). Este processo de queima modifica de maneira substancial a estrutura do material "verde" e fornece as bem conhecidas características de dureza, resistência mecânica, inércia química e física (PALMONARI; CARANI, 2005). As propriedades gerais dos materiais cerâmicos, em particular de pisos e azulejos, podem ser reconduzidas à sua composição e estrutura e são determinadas pelas modalidades de fabricação.

Os métodos de conformação do material são dois: extrusão e prensagem. A extrusão é utilizada para produtos como "cotto" e clinker, em que a massa das matérias primas é preparada em forma de pasta com conteúdo de umidade variável entre 15 e 20\%. A massa é forçada a passar por uma abertura que reproduz a secção transversal do produto, criando um tapete contínuo, oportunamente cortado. A prensagem é a técnica mais utilizada para produtos como grés porcelanato e monoqueima. A massa é preparada em forma de pó com umidade variável entre 4 e $7 \%$ e é comprimida entre a matriz e o punção da prensa, com pressões nominais entre 20 e $40 \mathrm{MPa}$.

A maioria dos produtos cerâmicos (neste contexto, piso e azulejo) é constituída por um suporte de massa cerâmica, que pode ser recoberto por uma capa vidrosa, genericamente chamada de "vidrado" ou esmalte. O produto esmaltado apresenta a superfície recoberta por uma camada de vidro que fornece importantes características estéticas (cor, brilho, decoração, efeitos) e técnicas (dureza, impermeabilidade), que dependem do tipo de esmalte e podem variar muito. No produto esmaltado é reconhecida uma descontinuidade de composição e uma mudança de características na espessura; os produtos não esmaltados apresentam uniformidade na espessura. Outras características importantes que a massa deve apresentar são fácil floculabilidade (no caso de preparação por via úmida); composição mineralógica que confere uma dilatação controlada; porosidade e 
constância dimensional compatíveis com os processos de esmaltação e queima. As matérias primas utilizadas na preparação de massas cerâmicas raramente são substâncias puras.

Renau (1994) define uma massa cerâmica como mistura equilibrada de matérias primas plásticas e não plásticas que cumprem uma série de exigências que as fazem úteis para a fabricação de produtos cerâmicos. Matérias primas plásticas são, principalmente, argila, caolim e bentonita; as não plásticas compreendem quartzo, feldspatos, carbonato de cálcio, talco e chamotas ${ }^{3}$. A relação entre matérias primas plásticas e não plásticas deve ser feita de maneira que confira à massa uma plasticidade suficiente para facilitar o processo de conformação do produto, por prensagem, e uma aceitável resistência mecânica ao produto formado, antes e depois da queima (BORDIGNON, 2004).

A capa vidrosa ${ }^{4}$ que cobre o suporte tem a estrutura de um líquido sub-resfriado, de altíssima viscosidade, com aparência de sólido à temperatura ambiente proporcionada por uma rigidez mecânica devida ao grande aumento da viscosidade de uma massa fundida. Por outro lado, por ter estrutura amorfa, não pode ser considerada sólida, pois falta-lhe a estrutura cristalina que caracteriza e define o estado sólido e não tem uma temperatura de fusão determinada.

Os vidros cerâmicos, ou esmaltes, são obtidos de misturas controladas de matérias primas inorgânicas e de vidrados "base", chamadas fritas ${ }^{5}$. Todos os esmaltes utilizados na produção industrial de pisos e azulejos contêm uma parte de fritas, em maior ou menor quantidade, na sua composição. Pode-se tratar de uma única frita ou de uma mistura de fritas de tipos diferentes; a proporção da parte "fritada" no esmalte depende do tipo de produto e do ciclo de queima. Entre as características fundamentais das fritas, podem-se enumerar: permitir o uso, no esmalte, de matérias primas solúveis em água, que na fusão se combinam com substâncias insolúveis, adquirindo esta característica; reduzir a toxicidade de alguns componentes, como o óxido de chumbo; aumentar os intervalos de fusão dos

\footnotetext{
${ }^{3}$ Chamota: restos de suporte cerâmico já queimado ou de refratário, moídos. Venturi (1986).

${ }^{4}$ Os vidros cerâmicos são preparados a partir de misturas que, na fusão, se unem intimamente ao suporte; trata-se de vidros, isto é, formas diferentes de alumino-silicatos fundidos, que podem conter ou não formações cristalinas em suspensão. Venturi (1986).

${ }^{5}$ Fritas: compostos vítreos, insolúveis em água, obtidos por fusão complexa de elementos de origem mineral e sintética e sucessivo resfriamento rápido; os componentes devem ter capacidade de "formar vidros", ou seja, de passar de uma estrutura cristalina a uma amorfa, por simples resfriamento. Renau (1994).
} 
esmaltes; permitir maior uniformidade do vidro; reduzir a presença de defeitos superficiais e aumentar a estabilidade das cores.

O "vidrado" deve cumprir uma série de funções, com respeito ao processo de fabricação do próprio produto (viscosidade e tensão superficial adequadas para aplicação e, ao longo do processo de queima, intervalos de fusão compatíveis com o processo de queima, distribuição homogênea no suporte, temporária permeabilidade aos gases do suporte, controle de dilatação, etc.) e às características exigidas no produto final (impermeabilidade, resistência à abrasão ou desgaste, insolubilidade em água e reagentes químicos com os quais pode entrar em contato, facilidade de limpeza, resistência mecânica adequada ao uso previsto, estética, brilho, cor, transparência ou opacidade, textura). Tais propriedades dependem da composição química, das condições de aplicação e de fatores inerentes ao processo de fabricação, como temperatura e tempo de maturação ${ }^{6}$, atmosfera do forno e ciclo térmico total.

\footnotetext{
${ }^{6}$ Maturação do esmalte: seqüência de fases na queima do esmalte (sinterização das partículas de frita, amolecimento progressivo do sinterizado, distribuição uniforme sobre o suporte, solidificação).
} 


\section{CLASSIFICAÇÃO DOS PRODUTOS CERÂMICOS}

É necessário introduzir o conceito de classificação dos produtos para poder distinguir produtos similares, mas que se destinam a utilizações diversas (SACMI, 2003).

Uma primeira distinção pode ser realizada separando os materiais cerâmicos em tradicionais e especiais ou avançados. Entre os tradicionais, estão normalmente incluídos compostos de óxidos naturais, como piso e azulejo, sanitários, louças, produtos de olaria e alguns tipos de refratários. Os especiais ou avançados são compostos de não-óxidos ou óxidos especiais, incluindo biocerâmicos, porcelanas elétricas e técnicas, cerâmicas para eletrônica, catalisadores e refratários especiais e não serão analisados neste contexto. Para melhor entender a composição de um cerâmico tradicional, pode-se generalizar a composição da massa para pisos ${ }^{7}$, que compreende materiais argilosos (fornecem plasticidade para obter uma forma definida e contêm alumínio e sílica, com parte de cálcio, ferro e titânio); materiais fundentes (feldspatos e nefelina, que na queima produzem fases vidrosas que agem como colante entre as partículas, contendo sódio, potássio, alumínio e sílica); materiais inertes (talco, sílica, carbonato de cálcio, contendo principalmente cálcio, magnésio e sílica) e aditivos (inorgânicos ou orgânicos, introduzidos na mistura em quantidades muito pequenas, $<1 \%$, melhorando a reologia ${ }^{8}$ das suspensões em água).

A classificação é baseada em padrões internacionais e em costumes comerciais. Os padrões internacionais são baseados no tipo de processo produtivo e na absorção da água do produto queimado. Os costumes comerciais são baseados em velhas nomenclaturas, como grés, maiólica, clinker, etc. A forma correta de abordagem, obviamente, deve integrar um conjunto completo de características tecnológicas.

A identificação e a descrição das tipologias de produtos cerâmicos disponíveis no mercado referem-se a características técnicas, além de estéticas, cujo parâmetro de avaliação principal é estabelecido pelas Normas ISO (PALMONARI; TIMELLINI,

\footnotetext{
${ }^{7}$ Para aprofundamentos em relação às características químico-físicas das matérias primas, remetese aos inúmeros manuais e textos específicos.

${ }^{8}$ Reologia (do grego: "reo" = escorrimento e "logo" = estudo): estudo do escorrimento de sólidos, no caso dos pós, e de líquidos, no caso das barbotinas.
} 
2000b). As normas atuais contêm, essencialmente, uma classificação de piso e azulejo cerâmico em grupos, uma definição das características que os produtos de cada grupo devem possuir em relação ao uso para o qual são destinados, uma descrição dos métodos de medição das diferentes características e uma indicação dos requisitos de aceitabilidade que os produtos de cada grupo devem respeitar para cada característica. Os requisitos representam, substancialmente, limites ou referências que os produtos devem respeitar para serem julgados de boa qualidade. As normas, portanto, garantem a retidão do relacionamento comercial, tutelando ambas as partes, mas, principalmente, o consumidor.

A cada denominação comercial corresponde o uso prevalecente, sugerido em função de o produto ser ou não esmaltado, ser ou não de espessura fina, etc. Dependendo do tipo de utilização (piso/azulejo; interno/externo), o produto cerâmico deverá apresentar boa ou ótima resistência às cargas, à retração, à flexão, à abrasão e às manchas, ou deverá formar desenhos geométricos regulares, exigindo dimensões rigorosamente calibradas. Ainda poderá ser utilizado em ambiente externo e sujeito a ciclos de gelo-degelo ou em climas úmidos e quentes, requerendo características diferentes de absorção, de pós-reatividade com água ou umidade e de cor da massa base. Resumindo, entre as qualidades finais para um produto cerâmico devem ser consideradas de primária importância a resistência mecânica e as características geométricas (calibragem e planicidade).

Baseado nestas considerações e em função das exigências de produção, de limites técnicos, de pedidos de mercado, de disponibilidade e de custo de matérias primas adequadas, as diferentes tipologias de pisos e azulejos cerâmicos podem ser esquematizadas em três grandes classes de produtos: revestimento (ou azulejo), piso e grés porcelanato.

Com relação ao uso como revestimento, os produtos cerâmicos são um dos primeiros materiais tecnológicos produzidos pelo homem, com funções artísticas, além das primárias funções higiênicas, com origem comprovada no século $\mathrm{V}$ a.C. Dentro da classificação geral de cerâmica para revestimento, encontram-se produtos obtidos com os processos de biqueima e monoqueima. São materiais que apresentam características importantes para o uso, como máxima estabilidade dimensional na queima (valores de contração praticamente nulos, < 1\%), porosidade entre $13 \%$ e $18 \%$ (como porcentagem de água absorvida), tensão limite de ruptura (do queimado) entre 20 e $25 \mathrm{Mpa}$. 
Considerando o piso, o uso de cerâmica vermelha com tal finalidade tem origem tão antiga que não é identificável, ao passo que a difusão de cerâmica esmaltada decorada é atribuível ao século XI. Uma classificação comercial divide as massas para monoqueima greificada em "vermelhas" e "brancas", que se distinguem pela natureza da argila que as compõe (concentração de ferro). As massas brancas apresentam melhor estabilidade dimensional e de porosidade. Entre os materiais para piso (pavimentação), o que melhor suporta usuras de qualquer tipo, em virtude da elevada dureza superficial, é o "grés porcelanato fine", ou, mais simplesmente, grés porcelanato. Possui também ótimas propriedades antigelivas, de resistência mecânica à flexão e à compressão, de resistência ao ataque químico e às manchas. A denominação "grés porcelanato" é suficiente para chamar a atenção nas características do produto; "grés" indica uma massa compacta, constituída de várias fases cristalinas numa matriz vidrosa; o termo "porcelanato" tem clara raiz etimológica no termo "porcelana", o material cerâmico mais nobre, conhecido e prezado há séculos. É um produto de ótimas características técnicas, apresentando elevada resistência mecânica e valores de absorção de água muito baixos, freqüentemente $<0,1 \%$. No contexto da indústria cerâmica, o grés assumiu um papel sempre crescente, alcançando os mais diversificados segmentos. Se no passado o produto era prezado apenas pelas características técnicas, hoje demonstra notáveis potencialidades estéticas, que permitem a penetração em segmentos mais sofisticados. Do ponto de vista cerâmico, o grés não é um produto novo, pois tem origem em tecnologias de produção já utilizadas no passado, mas hoje obsoletas. O atual desenvolvimento deve ser associado à introdução de adequadas composições químico-mineralógicas inovadoras, coordenadas a modernas tecnologias, como a conformação de alta pressão, recentes técnicas de decoração e a queima rápida estendida a grandes formatos.

Conforme a classificação da ISO 13006 (1998), mais adiante detalhada, o grés porcelanato é incluído no Grupo Bla, que compreende materiais greificados e caracterizados por valores de porosidade inferiores a 0,5\% (como absorção de água). Na realidade, os produtos industriais apresentam uma porosidade inferior à prevista pela norma, geralmente $<0,1 \%$.

Com relação às denominações técnicas, as normas prevêem uma classificação diferente da comercial, baseada em apenas dois parâmetros: o método de 
conformação (extrusão ou prensagem) e a porosidade (medida com a determinação da absorção de água).

A absorção de água vem a ser a medida convencional da porosidade de uma peça cerâmica, pois mede a quantidade de água que, em particulares condições experimentais de embebição, o produto pode absorver. A absorção acontece através dos poros do material que estão em comunicação com a superfície externa, portanto este parâmetro constitui uma medida da sua quantidade, que é definida como "porosidade aberta". A "porosidade fechada", ao contrário, é constituída pelos poros não intercomunicantes, não acessíveis à superfície externa. A absorção de água fornece, então, uma indicação imediata da estrutura do material. Um valor elevado de absorção corresponde a uma estrutura altamente porosa. Ao contrário, uma baixa absorção indica uma estrutura compacta (greificada). Com base nestes dois parâmetros, os produtos cerâmicos são divididos em 9 grupos.

Para os produtos cerâmicos existem, por conseguinte, duas classificações distintas, não ligadas uma à outra por uma relação específica. Esta posição deriva do fato que as classificações comerciais são anteriores à classificação técnica estabelecida pela norma e, para muitos produtos, são utilizadas apenas localmente, pois algumas denominações ou produtos são tipicamente regionais.

A classificação ISO é a única possibilidade de uma norma geral, válida no mundo inteiro, segundo a qual todos os produtos podem encontrar colocação.

\subsection{Normas aplicáveis}

Duas são as normas ISO para produtos cerâmicos (pisos e azulejos): a 10545 e a 13006. A ISO 10545 (1997) é relativa aos métodos de teste previstos para a medição das características de qualificação de pisos e azulejos cerâmicos em função das condições de utilização. Esta norma é composta de 17 partes, uma para cada método de teste. $\mathrm{Na}$ realidade, a parte 17 , relativa à resistência ao escorregamento, é vazia, pois não prevê métodos de testes, sobre os quais não foi encontrado acordo. A ISO 13006 é relativa a definições, critérios de classificação e requisitos; o revestimento cerâmico é classificado em grupos, dependendo do método de conformação e do valor de absorção de água do produto acabado. Uma 
das novidades substanciais presente nesta norma é representada pela introdução, na classificação dos produtos, do Grupo Bla, no qual convergem as peças obtidas para conformação com prensagem e que apresentam absorção de água não superior a 0,5\%; a tal grupo pertencem muitas das peças esmaltadas e não, denominadas comercialmente "grés porcelanato". Pelo que concerne ao requisito relativo à resistência ao escorregamento acima citado, é prescrito apenas especificar o método de teste adotado. Concluindo, para os produtos cerâmicos existem normas válidas no mundo inteiro (Norma ISO). Estas normas fornecem uma classificação dos produtos em 9 grupos; a cada grupo é associada uma norma específica que detalha os requisitos que os produtos do grupo devem apresentar. Em conseqüência disso, para definir e identificar um tipo de produto cerâmico, deve-se conhecer a classe a que pertence, na classificação comercial, e o grupo da classificação ISO. A Tabela 1 esquematiza a classificação ISO dos produtos cerâmicos.

Tabela 1 - Classificação de produtos cerâmicos pela Norma ISO 13006

\begin{tabular}{|l|c|c|c|c|}
\hline \multirow{2}{*}{$\begin{array}{l}\text { Método de } \\
\text { conformação }\end{array}$} & \multicolumn{4}{|c|}{ Absorção de água A.A. (\%) } \\
\cline { 2 - 5 } & $\begin{array}{c}\text { Grupo I: } \\
\mathrm{AA}<3\end{array}$ & $\begin{array}{c}\text { Grupo IIA: } \\
3<\mathrm{AA}<6\end{array}$ & $\begin{array}{c}\text { Grupo IIB: } \\
6<\mathrm{AA}<10\end{array}$ & $\begin{array}{c}\text { Grupo III: } \\
10<\mathrm{AA}\end{array}$ \\
\hline Extrusão: $\mathrm{A}$ & $\mathrm{Al}$ & $\mathrm{Alla}$ & $\mathrm{Allb}$ & $\mathrm{Alll}$ \\
\hline Prensagem: $\mathrm{B}$ & $\begin{array}{c}\mathrm{Bla} \quad \mathrm{AA}<0,5 \\
\mathrm{Blb} 0,5<\mathrm{AA}<3\end{array}$ & $\mathrm{Blll}$ & $\mathrm{Bllb}$ & BIII \\
\hline
\end{tabular}

(Adaptada de ISO, 1998)

Para facilitar a compreensão da classificação dos produtos cerâmicos, na Tabela 2 encontra-se uma distribuição das tipologias diferentes em função da classificação ISO. Neste contexto, considerando os produtos de monoqueima, todos pertencem ao grupo B: produtos obtidos para prensagem.

Tabela 2 - Relação entre tipo de produto e classificação da Norma ISO 13006

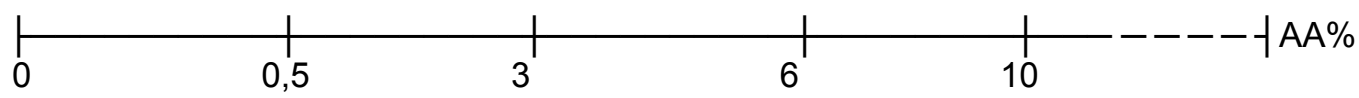

- Grupo Bla + Grupo Blb + Grupo Blla + Grupo Bllb + Grupo BIII -

F Grés Porcelanato + Piso $\quad$ Revestimento - 
Os países anglo-saxões, mais especificamente os Estados Unidos, embora tenham participado ativamente da preparação das normas ISO, não estavam colaborando construtivamente para sua adoção; o motivo principal desta demora é atribuído ao diferente sistema de unidades de medida. Esta realidade, até 2003, dificultava o relacionamento comercial com um dos maiores importadores de produtos cerâmicos e precisou ser cuidadosamente considerada nas negociações e no fornecimento. Nos Estados Unidos existem dois Órgãos de Normalização: a ANSI e a ASTM. A ANSI (American National Standard Institute) predispõe as definições, a classificação, a marcação e os requisitos; a norma referente à cerâmica era a ANSI A 137.1, de 1988, hoje substituída pela ANSI AS 4662 (2003). Recentemente a ANSI publicou a série AS 4459 (1997-1999), de 4459.1 até 4459.16, que absorve a ISO 10545. Oliveira (2001) chama a atenção sobre a norma ANSI A 137.1 (1980), que comporta uma classificação diversa da ISO, embora também relacionada aos valores de absorção de água, resumida na Tabela 3. A ASTM (American Society for Testing Materials) predispõe e atualiza os métodos de teste.

Tabela 3 - Classificação de produtos cerâmicos pela Norma ANSI A 137.1

\begin{tabular}{|l|c|c|c|c|}
\hline \multirow{2}{*}{$\begin{array}{l}\text { Peças cerâmicas } \\
\text { prensadas }\end{array}$} & \multicolumn{4}{|c|}{ Absorção de água A.A. (\%) } \\
\cline { 2 - 5 } & $\mathrm{AA}<0,5$ & $0,5<\mathrm{AA}<3$ & $3<\mathrm{AA}<7$ & $7<\mathrm{AA}<18$ \\
\hline Pavimentos & muito vitrificado & Vitrificado & semi-vitrificado & não vitrificado \\
\hline Revestimentos & - & - & semi-vitrificado & não vitrificado \\
\hline
\end{tabular}

Esta situação incômoda está hoje aparentemente resolvida com a publicação das ANSI 4662 e 4459 que, juntas, absorvem integralmente as ISO 10545 e 13006.

Para a qualificação das peças cerâmicas, os métodos de teste apresentam freqüentemente, dependendo do país emissor, parâmetros operativos diferentes e, algumas vezes, a determinação da mesma propriedade não é prevista em todas as normas. Em muitos casos, para os requisitos impostos, é impossível operar uma comparação direta. Notáveis diversidades aparecem, seja para classificação, seja para controle, não justificadas por reais diferenças de produção e de utilização das peças cerâmicas (VENTURI, 1986).

A apresentação das informações detalhadas e completas a respeito da classificação ISO é evidenciada nas Tabelas 4 e 5, que indicam, respectivamente, a 
classificação dos produtos cerâmicos em função das denominações técnicocomerciais e as características técnicas para os diferentes produtos cerâmicos.

No caso do Brasil, as normas vigentes são 3: a ABNT 13816, que indica a terminologia a ser utilizada; a 13817, referente à classificação dos produtos; a 13818, que estabelece especificações e métodos de teste. Na prática, as ABNT (1997) absorvem integralmente as ISO 10545 e 13006. Muito recentemente, em fevereiro de 2007, a ABNT (2007) lançou uma quarta norma para produtos cerâmicos, a ABNT 15463, específica para grés porcelanato, que determina requisitos técnicos mais exigentes, na tentativa de atender às crescentes necessidades e expectativas do mercado consumidor (PASCHOAL, 2007).

$\mathrm{Na}$ Europa, a necessidade de qualificar o produto e, conseqüentemente, valorizálo para enfrentar a crescente concorrência, a existência de outros mercados produtores mais favorecidos em termos de custos e a busca de proteção contra contrafações ou concorrência desleal levaram a um interessante e bem sucedido desenvolvimento de sistemas de certificação, seja em termo de qualidade, seja de registro de indicações geográficas.

Analisando o quadro normativo europeu (PALMONARI; CARANI, 2005), a conformidade das peças cerâmicas àquilo que é prescrito pelas normas pode ser simplesmente declarada pelo produtor ou certificada por uma entidade apropriada que, com base no controle do produto e na verificação da confiabilidade da gestão do processo de produção, confere ao produto um Selo de Qualidade.

$\mathrm{Na}$ Itália, o selo Certiquality - UNI certifica os produtos cerâmicos por meio de atividades de testes, inspeções e controle, tornando possível deduzir que o produto não apenas responde aos requisitos da norma técnica de referência, mas também que todas as fases do processo de produção são adequadamente controladas. Assim, mesmo que não seja possível efetuar todos os testes, a constância da qualidade de produção pode ser razoavelmente garantida (CERTIQUALITY, 2005). É fundamental ressaltar que este é um selo de certificação de produto, diferente da ISO 9000, que certifica o sistema.

A Itália desenvolveu também o selo "Ceramica di qualitá", que tutela a denominação de origem da produção italiana de cerâmica artística e tradicional e dos produtos industriais. O selo cobre a produção de cerâmica decorativa, louça e cerâmica para uso alimentar, piso, azulejo e sanitários. As condições para a obtenção do selo se referem à origem e à qualidade. No caso da origem, o produto, 
em todas as fases do processo de produção, deve ser realizado em território da União Européia, sem utilizar produtos semimanufaturados provenientes de outros países. No caso da qualidade, o produto cerâmico deve ser cadastrado na lista dos produtores de cerâmica de qualidade, criada pelas Câmaras de Comércio locais, e deve estar de acordo com as características definidas pelas normas vigentes.

Em âmbito europeu, atendendo a uma diretriz comunitária sobre a segurança dos materiais para construção que exige a conformidade das obras civis a normas de segurança dos bens e dos usuários (ASSOPIASTRELLE, 2004), a partir do $1^{\circ}$ de dezembro de 2005, é obrigatório o selo "CE" para a comercialização e livre circulação de pisos e azulejos cerâmicos. Observe-se que o selo "CE" é de "idoneidade", não de qualidade: os produtos devem ser seguros, independentemente da qualidade comercial.

Na Europa, para pisos e azulejos, existe também o selo "Ecolabel", de excelência ambiental.

Como relatado acima, existe um denominador comum em termos de segurança do produto (o selo $\mathrm{CE}$ ). Até pouco tempo atrás, a certificação da qualidade era realizada em âmbito nacional, com referência às normas nacionais, nem sempre harmonizadas, podendo gerar barreiras à livre circulação de mercadorias na Europa. Para ultrapassar este obstáculo, recentemente foi criado um selo europeu de qualidade, o KEYMARK, com função de denominador comum para a certificação do produto. Os vários países da EU harmonizaram as normas de qualidade, permitindo a geração de regras unívocas de certificação de produto, hoje reconhecidas e aceitas internacionalmente.

É importante lembrar que as normas não constituem lei, mas uma referência oficial a respeito da qualidade e das características dos diferentes tipos de pisos e azulejos. As normas são regras técnicas que permitem, aos produtores e aos clientes, estabelecer e demonstrar se um determinado produto é de boa qualidade. Deve-se ressaltar que o respeito das normas é técnico; o produtor cerâmico não é obrigado a produzir piso e azulejo conformes as normas. É também claro que, se o produtor assume o compromisso, frente ao consumidor, de ter operado conforme as normas, passa a ter essa obrigação. 
Tabela 4 - Classificação dos produtos cerâmicos em função das denominações técnico-comerciais (Adaptada de Palmonari, 2000b)

\begin{tabular}{|c|c|c|c|c|c|c|c|c|c|c|c|c|c|c|c|c|}
\hline \multirow{2}{*}{$\begin{array}{l}\text { Denominação } \\
\text { comercial }\end{array}$} & \multicolumn{2}{|c|}{ Superfície } & \multicolumn{3}{|c|}{ Estrutura do suporte } & \multicolumn{2}{|c|}{ Método de formação } & \multicolumn{2}{|c|}{ Cor suporte } & \multirow{2}{*}{$\begin{array}{c}\begin{array}{c}\text { Formatos } \\
\text { previstos }\end{array} \\
{[\mathrm{cm}]}\end{array}$} & \multirow{2}{*}{$\begin{array}{c}\text { Ciclo } \\
\text { tecnológico }\end{array}$} & \multicolumn{4}{|c|}{ Destinação prevista } & \multirow{2}{*}{$\begin{array}{c}\text { Grupo } \\
\text { ISO }\end{array}$} \\
\hline & esmaltada & $\begin{array}{c}\text { não } \\
\text { esmaltada }\end{array}$ & poroso & greificado & A.A.(\%) & prensagem & extrusão & branco & outro & & & piso & parede & interno & externo & \\
\hline Maiólica & $\bullet$ & - & - & - & $15-25$ & - & - & - & - & $\begin{array}{l}15 \times 15 \\
15 \times 20 \\
20 \times 20\end{array}$ & $\begin{array}{l}\text { biqueima } \\
\text { massa seco }\end{array}$ & - & - & $\bullet$ & - & BIII \\
\hline Cottoforte & - & - & - & - & $7-15$ & $\bullet$ & - & - & $\bullet$ & $\begin{array}{l}15 \times 25 \\
20 \times 20 \\
20 \times 30\end{array}$ & $\begin{array}{l}\text { biqueima } \\
\text { massa seco }\end{array}$ & - & - & - & - & BIII \\
\hline $\begin{array}{l}\text { Terralha pasta } \\
\text { branca }\end{array}$ & $\bullet$ & - & $\bullet$ & - & $10-20$ & - & - & $\bullet$ & - & $15 \times 15$ & $\begin{array}{c}\text { biqueima } \\
\text { massa úmida }\end{array}$ & - & - & $\bullet$ & - & BIII \\
\hline \begin{tabular}{|l|} 
Monoqueima \\
vermelha
\end{tabular} & $\bullet$ & - & - & $\bullet$ & $2-10$ & $\bullet$ & - & - & $\bullet$ & $\begin{array}{l}10 \times 20 \\
20 \times 30 \\
30 \times 30 \\
40 \times 40\end{array}$ & $\begin{array}{l}\text { monoqueima } \\
\text { massa úmida }\end{array}$ & $\bullet$ & - & $\bullet$ & - & $\begin{array}{c}\text { Bl } \\
\text { Blla } \\
\text { Bllb }\end{array}$ \\
\hline $\begin{array}{l}\text { Monoqueima } \\
\text { clara }\end{array}$ & - & - & - & - & $2-7$ & - & - & - & - & $\begin{array}{l}30 \times 30 \\
40 \times 40 \\
\end{array}$ & $\begin{array}{l}\text { monoqueima } \\
\text { massa úmida }\end{array}$ & - & - & - & - & $\begin{array}{l}\mathrm{BI} \\
\mathrm{BII}\end{array}$ \\
\hline $\begin{array}{l}\text { Monoporosa } \\
\text { (verm./clara) }\end{array}$ & $\bullet$ & - & $\bullet$ & - & $>10$ & - & - & - & $\bullet$ & $20 \times 20$ & $\begin{array}{l}\text { monoqueima } \\
\text { massa úmida }\end{array}$ & - & - & - & - & BIII \\
\hline $\begin{array}{l}\text { Presso- } \\
\text { esmaltadura }\end{array}$ & $\bullet$ & - & - & $\bullet$ & $<3$ & $\bullet$ & - & $\bullet$ & $\bullet$ & - & - & - & - & $\bullet$ & - & $\mathrm{BI}$ \\
\hline Clinker & $\bullet$ & $\bullet$ & - & $\bullet$ & $2-6$ & - & $\bullet$ & $\bullet$ & $\bullet$ & $\begin{array}{l}12 \times 24 \\
20 \times 20 \\
30 \times 30\end{array}$ & $\begin{array}{l}\text { monoqueima } \\
\text { massa úmida }\end{array}$ & $\bullet$ & $\bullet$ & $\bullet$ & $\bullet$ & $\begin{array}{c}\text { Al } \\
\text { Alla }\end{array}$ \\
\hline Cotto & - & - & - & - & $3-15$ & - & - & - & - & $\begin{array}{l}25 \times 25 \\
20 \times 40 \\
30 \times 30 \\
40 \times 60 \\
\end{array}$ & $\begin{array}{c}\text { monoqueima } \\
\text { massa seca }\end{array}$ & - & - & - & - & $\begin{array}{l}\text { Alla } \\
\text { Allb } \\
\text { Alll }\end{array}$ \\
\hline Grés vermelho & - & $\bullet$ & - & $\bullet$ & $1-4$ & • & - & - & - & $7,5 \times 15$ & $\begin{array}{l}\text { monoqueima } \\
\text { massa seca } \\
\text { massa úmida }\end{array}$ & $\bullet$ & - & $\bullet$ & $\bullet$ & $\mathrm{Blb}$ \\
\hline \begin{tabular}{|l|} 
Grés \\
porcelanato
\end{tabular} & $\bullet$ & $\bullet$ & - & - & $<0,5$ & $\bullet$ & - & $\bullet$ & $\bullet$ & $\begin{array}{l}20 \times 30 \\
30 \times 30 \\
40 \times 40\end{array}$ & $\begin{array}{l}\text { monoqueima } \\
\text { massa úmida }\end{array}$ & $\bullet$ & $\bullet$ & $\bullet$ & $\bullet$ & Bla \\
\hline
\end{tabular}

A.A. $(\%)=$ absorção de água, em \% ponderal. 
Tabela 5 - Característica técnicas dos produtos cerâmicos conforme a Norma ISO 13006 (Adaptada da SACMI, 2003)

\begin{tabular}{|c|c|c|c|c|c|c|}
\hline \multirow[t]{3}{*}{ Características } & \multirow{3}{*}{$\begin{array}{l}\text { Referência } \\
\text { ISO }\end{array}$} & \multicolumn{5}{|c|}{ Valores prescritos pela Norma } \\
\hline & & \multirow[t]{2}{*}{ REVESTIMENTO } & \multicolumn{3}{|c|}{ PISO } & \multirow[t]{2}{*}{ GRÉS PORCELANATO } \\
\hline & & & Grupo Blb & Grupo Blla & Grupo Bllb & \\
\hline Absorção de água & 10545.3 & $>10,<20 \%-\min .9 \%$ & $>0,5,<3 \%(\max .3,3)$ & $>3,<6 \%(\max .6,5)$ & $>6,<10 \%(\max .11)$ & $\leq 0,5 \%$ \\
\hline Módulo de ruptura ${ }^{(1)}$ & 10545.4 & $12-15 \mathrm{~N} / \mathrm{mm}^{2}$ & $30 \mathrm{~N} / \mathrm{mm}^{2}(\min .27)$ & $>22 \mathrm{~N} / \mathrm{mm}^{2}(\min .20)$ & $>18 \mathrm{~N} / \mathrm{mm}^{2}(\min .16)$ & $>35 \mathrm{~N} / \mathrm{mm}^{2}(\min .32)$ \\
\hline Carga de ruptura ${ }^{(1)}$ & 10545.4 & $\min .600-\min .200 \mathrm{~N}$ & $\min .1100-\min .700 \mathrm{~N}$ & $\min .1000-\min .600 \mathrm{~N}$ & $\min .800-\min .500 \mathrm{~N}$ & $\min .1300-\min .700 \mathrm{~N}$ \\
\hline $\begin{array}{l}\text { Resistência a abrasão profunda } \\
\text { (2) }\end{array}$ & 10545.6 & $\begin{array}{c}\text { Declarada pelo } \\
\text { Produtor }\end{array}$ & $\max .175 \mathrm{~mm}^{3}$ & $345 \mathrm{~mm}^{3}$ & $540 \mathrm{~mm}^{3}$ & $<175 \mathrm{~mm}^{3}$ \\
\hline $\begin{array}{l}\text { Resistência a abrasão superficial } \\
(2)\end{array}$ & 10545.7 & $\begin{array}{l}\text { Declarada pelo } \\
\text { Produtor }\end{array}$ & Declarada pelo Produtor & Declarada pelo Produtor & Declarada pelo Produtor & Declarada pelo Produtor \\
\hline Coeficiente de dilatação & 10545.8 & Teste disponível & Teste disponível & Teste disponível & Teste disponível & Teste disponível \\
\hline Resistência a choque térmico & 10545.9 & Teste disponível & Teste disponível & Teste disponível & Teste disponível & Teste disponível \\
\hline Expansão a umidade & 10545.10 & Teste disponível & Teste disponível & Teste disponível & Teste disponível & Teste disponível \\
\hline Resistência a cavillo & 10545.11 & Sob pedido & Sob pedido ${ }^{(2)}$ & Sob pedido ${ }^{(2)}$ & Sob pedido ${ }^{(2)}$ & Sob pedido \\
\hline Resistência a gelo & 10545.12 & Teste disponível & $\begin{array}{c}\text { Pedido para uso externo } \\
\text { com gelo }\end{array}$ & Declarada pelo Produtor & Declarada pelo Produtor & Sob pedido \\
\hline Resistência a produtos químicos & 10545.13 & Classe GB min. & Classe GB $\underset{(3)}{\min .-U B} \min$. & Classe GB $\min _{(3)}$.-UB min. & Classe GB min.-UB min. & Classe GB min. \\
\hline Resistência a ácidos e bases & 10545.13 & Teste disponível & Teste disponível & Declarada pelo Produtor & Declarada pelo Produtor & Teste disponível \\
\hline Resistência a manchas & 10545.14 & Classe 3 min. & Classe 3 min. ${ }^{(4)}$ & Classe 3 min. ${ }^{(4)}$ & Classe 3 min. ${ }^{(4)}$ & Classe 3 min. \\
\hline Extração de $\mathrm{Pb}$ e $\mathrm{Cd}$ dos vidros & 10545.15 & Teste disponível & - & - & - & Teste disponível \\
\hline Diferença de cor & 10545.16 & Teste disponível & Teste disponível & Teste disponível & Teste disponível & Teste disponível \\
\hline Coeficiente de fricção ${ }^{(2)}$ & 10545.17 & Teste disponível & Declarada pelo Produtor & Declarada pelo Produtor & Declarada pelo Produtor & Teste disponível \\
\hline
\end{tabular}

As normas 10545.1 e 10545.2, relativas às metodologias de aceitação da amostra e às determinações dimensionais e de qualidade das superfícies, não são reproduzidas na tabela por exigências de espaço.

(1) Dependendo da espessura (<7,5 mm e $\geq 7,5 \mathrm{~mm}$ ).

(2) A ser realizado apenas no caso de uso como piso.

(3) Materiais não esmaltados.

(4) Materiais esmaltados 


\subsection{Síntese}

Do ponto de vista normativo, é possível desdobrar a análise do setor cerâmico em dois focos: um primeiro, puramente técnico, que padroniza os aspectos de classificação dos produtos e a metodologia de teste; um segundo, técnico-comercial, que prevê sistemas de certificação de qualidade e de origem do produto. Este último conjunto de normas visa a garantir a qualidade do produto em termos de sistema de qualidade, como no caso da ISO 9000, e em termos absolutos, assumindo assim uma conotação comercial, orientada para sustentar ações de marketing e a imagem dos produtores em âmbito internacional. As Tabelas 6 e 7 concentram as informações principais do enfoque normativo atual.

Tabela 6 - Normas técnicas aplicáveis

\begin{tabular}{|l|c|c|}
\hline ENTE NORMATIZADOR / OBJETIVO & ITÁLIA & BRASIL \\
\hline Ente Normatizador & ISO & ABNT \\
\hline Terminologia / Definições & 13006 & 13816 \\
\hline Classificação & 13006 & 13817 \\
\hline Especificações e métodos de teste & 10545 & 13818 \\
\hline Grés porcelanato: requisitos técnicos & 13006 & 15463 \\
\hline
\end{tabular}

Tabela 7 - Sistemas de certificação

\begin{tabular}{|l|c|c|c|c|}
\hline \multirow{2}{*}{ OBJETIVO } & \multicolumn{2}{|c|}{ ITÁLIA } & \multicolumn{2}{c|}{ BRASIL } \\
\cline { 2 - 5 } & ENTE & NORMA / SELO & ENTE & NORMA \\
\hline Qualidade de sistema & ISO & 9000 & ISO & 9000 \\
\hline $\begin{array}{l}\text { Qualidade do produto } \\
\text { (Conformidade à norma e controle de } \\
\text { processo) }\end{array}$ & UNI & Certiquality & - & - \\
\hline $\begin{array}{l}\text { Denominação de Origem (produto) } \\
\text { Segurança dos materiais para } \\
\text { construção (idoneidade) }\end{array}$ & - & Ceramica di qualitá & - & - \\
\hline Excelência ambiental & - & CE & - & - \\
\hline Empresa de qualidade & ISO & Ecolabel & - & - \\
\hline
\end{tabular}


Uma rápida observação das informações resumidas na Tabela 6 evidencia que, do ponto de vista técnico, o Brasil está alinhado com os maiores concorrentes mundiais.

A Tabela 7, por outro lado, chama a atenção para a falta (ou atraso) do desenvolvimento de estratégias comerciais mais sofisticadas, que poderiam ser implementadas, até seguindo o exemplo italiano.

Vale ressaltar que, em se tratando de estratégias de mercado nacional, o estímulo não pode ser originado por produtores isolados, mas pelas Associações de categoria ou por Centros de Pesquisa, que no caso poderiam se transformar nos próprios certificadores. 


\section{O MERCADO CERÂMICO}

Tanto associações de categoria, como órgãos públicos e privados recolhem e elaboram anualmente um grande volume de dados a respeito de produção, vendas e exportações, disponibilizando informações úteis para o entendimento dos mercados e das relativas tendências. Utilizando fontes diferentes, é comum encontrar dados nem sempre concordantes e, por isso, é indispensável um grande cuidado com a escolha das fontes. Nos últimos anos, as associações de categoria e as entidades oficiais têm demonstrado ser fontes confiáveis.

Dentro do grande volume de dados disponíveis, para se ter uma clara imagem geral dos mercados, é possível limitar a análise a dois tipos de informações: produção e exportação, esta estritamente relacionada ao consumo. Nos capítulos a seguir, portanto, os mercados mundial, italiano e nacional são apresentados com base em produções e exportações.

Outro aspecto a salientar é que a disponibilidade de dados atualizados é dificultada pela sua elaboração, existindo, conseqüentemente, um sensível atraso entre a disponibilidade das informações e o período de referência.

Os dados consolidados mais recentes, no ato da redação da presente dissertação, referem-se ao ano 2004 e são disponibilizados pelas associações de categoria italiana (ASSOPIASTRELLE) e brasileira (ANFACER).

\subsection{O mercado mundial}

Gambuli (2001) apresenta uma imagem bem completa e articulada do mercado mundial, resultado da análise dos fluxos de produção e exportação da última década (1990 -2000) de cada área geográfica. Trabalho similar, com referência ao ano 2001, é produzido por Sezzi (2002). Embora alguns dados não estejam perfeitamente de acordo com os de Gambuli, as diferenças entram na margem de erro das fontes e podem ser desconsideradas. Resultados e valores são explicitados nas Tabelas 8 e 9. 
Tabela 8 - Produção mundial na década 1990-2000 e em 2001, dividida por áreas geográficas

\begin{tabular}{|c|c|c|c|c|c|c|c|c|c|c|c|c|c|c|c|c|c|c|c|}
\hline \multirow{2}{*}{$\begin{array}{l}\text { Região } \\
\text { Produção }\end{array}$} & \multicolumn{3}{|c|}{ Europa } & \multicolumn{2}{|c|}{ Leste Europeu } & \multicolumn{3}{|c|}{ NAFTA } & \multicolumn{2}{|c|}{ América do Sul } & \multicolumn{4}{|c|}{ Oriente Médio } & \multirow[t]{2}{*}{ China } & \multicolumn{2}{|c|}{ Ásia } & \multirow{2}{*}{\begin{tabular}{|l|} 
África \\
Total \\
\end{tabular}} & \multirow[t]{2}{*}{ TOTAL } \\
\hline & Itália $^{(1)}$ & Espanha & Total & URSS & \begin{tabular}{|l|} 
Total \\
\end{tabular} & México & EUA & Total & Brasil $^{(2)}$ & Total & Turquia $^{(3)}$ & Iran & Em.Ar. & Total & & İ́ndia & Total & & \\
\hline 1990 & 447 & 219 & 860 & 55 & 130 & 35 & 50 & 88 & 190 & 261 & 52 & 24 & 7 & 100 & 200 & & 280 & 30 & 1960 \\
\hline 2000 & 632 & 621 & 1460 & 25 & 150 & 130 & 62 & 200 & 453 & 543 & 175 & 60 & 30 & 270 & 1600 & 85 & 657 & 95 & 5000 \\
\hline$\Delta \%$ & $+41 \%$ & $+184 \%$ & $+71 \%$ & $-55 \%$ & $+15 \%$ & $+271 \%$ & $+24 \%$ & $127 \%$ & $+138 \%$ & $+108 \%$ & $+236 \%$ & $+150 \%$ & $+329 \%$ & $+170 \%$ & $+700 \%$ & & $+208 \%$ & $+217 \%$ & $+155 \%$ \\
\hline 2001 & 638 & 638 & 1476 & n.d. & n.d. & n.d. & n.d. & 193 & 473 & 579 & n.d. & n.d. & n.d. & n.d. & 1700 & n.d. & 860 & 115 & 5000 \\
\hline
\end{tabular}

Obs.: dados em $\mathrm{Mm}^{2}$.

(1) A participação da Itália no total mundial passou de 23\% em 1990 para 12,6\% em 2000.

(2) O Brasil representa $83 \%$ da produção da área.

(3) A Turquia representa $65 \%$ da produção da área.

n.d.: dado não disponível

Tabela 9 - Fluxo de exportações

\begin{tabular}{|l|r|r|r|r|r|r|}
\hline \multirow{2}{*}{ Exportação de: } & \multicolumn{7}{|c|}{ Exportação para: } \\
\cline { 2 - 7 } & \multicolumn{1}{|c|}{ Europa } & \multicolumn{1}{c|}{ América } & \multicolumn{1}{c|}{ Ásia } & \multicolumn{1}{c|}{ África } & Oceania & \multicolumn{1}{c|}{ TOTAL } \\
\hline Itália & $300(70 \%)$ & $72(17 \%)$ & $31(7 \%)$ & $17(4 \%)$ & $12(2 \%)$ & $435(100 \%)$ \\
\hline Espanha & $145(46 \%)$ & $69(22 \%)$ & $72(23 \%)$ & $21(7 \%)$ & $5(2 \%)$ & $312(100 \%)$ \\
\hline Brasil & $4(7,5 \%)$ & $40(85 \%)$ & $0,5(1 \%)$ & $2(4 \%)$ & $1(2,5 \%)$ & $47,5(100 \%)$ \\
\hline Turquia & $34(67 \%)$ & $7(13 \%)$ & $9(18 \%)$ & - & $2(3 \%)$ & $52(100 \%)$ \\
\hline
\end{tabular}

Obs.: dados em $\mathrm{Mm}^{2}$; a percentagem refere-se ao total de exportações do país. 
Analisando a tabela 8, é interessante observar como, ao longo de uma década, se alteraram os dados de produção dos produtores "chave" no mercado mundial. Neste contexto, como já antes evidenciado, é desconsiderada a China, por representar um fenômeno único de desenvolvimento e por ser um mercado que ainda apresenta anomalias e instabilidades.

A Itália manteve um crescimento positivo e a liderança mundial como produtor. A Espanha quase dobrou a produção, no mesmo período, alcançando o líder. O Brasil também apresenta um crescimento consistente, mantendo a posição de terceiro maior produtor. Em termos de produção, alguns países podem ser considerados "emergentes", seja pelo incremento relativo da produção, seja pela significância do volume absoluto, como o México e a Turquia. Na opinião do autor, nos próximos anos a Turquia representará uma ameaça para os produtores europeus, considerando a proximidade geográfica, a inclusão no mercado único da Europa, o alto volume de investimentos que está estavelmente recebendo e a excelente qualidade das matérias primas disponíveis localmente. Similarmente, o México tenderá a substituir grande parte da produção brasileira destinada aos Estados Unidos, em consideração da participação no NAFTA, da maior proximidade e do constante crescimento da qualidade dos produtos.

A observação da tabela 9 confirma as ameaças, podendo verificar o principal destino das exportações de Itália e Brasil, respectivamente Europa e Estados Unidos. Nesta situação, a Itália goza de situação privilegiada, pois detém a liderança mundial de tecnologia e design, o que muito dificulta a substituição dos próprios produtos. O Brasil, pelo contrário, não possui pontos de força e alavancagem significativos, exportando produtos de qualidade comum. $\mathrm{Na}$ Europa existe alta produção, alto consumo e um grande fluxo cruzado de importação e exportação. $O$ Brasil exporta uma percentagem limitada da produção.

A Tabela 10 recolhe dados referentes ao consumo de produtos cerâmicos no mundo em 2004 (ASSOPIASTRELLE, 2006). 
Tabela 10 - Consumo mundial de produtos cerâmicos em 2004

\begin{tabular}{|c|c|}
\hline Países & Consumo total $2004\left[\mathrm{Mm}^{2}\right]$ \\
\hline China & 2402 \\
\hline Europa Ocidental & 567 \\
\hline Europa centro- oriental & 488 \\
\hline Brasil & 449 \\
\hline Ásia e África sub-sahara & 377 \\
\hline Espanha & 363 \\
\hline América latina & 333 \\
\hline América do Norte & 327 \\
\hline Oriente médio e África do Norte & 265 \\
\hline Itália & 192 \\
\hline Austrália & 41 \\
\hline Outros & 1116 \\
\hline Total & 6919 \\
\hline
\end{tabular}

\subsection{O mercado italiano}

A indústria italiana de pisos e azulejos cerâmicos apresenta-se como líder no panorama mundial, precedida em volume total de produção apenas pela China, que, porém, só em 2003 começa a ter expressividade como exportadora. Em 2004 a Itália totaliza uma produção de $589,2 \mathrm{Mm}^{2}$, o que corresponde a $9 \%$ da produção mundial e a $43 \%$ da européia. O faturamento total alcança 5,33 bi de Euro e representa $35 \%$ do comércio internacional de placas cerâmicas, resultado obtido exportando 412,5 $\mathrm{Mm}^{2}$, correspondente a $71 \%$ das vendas totais, dirigidos a mais de 180 países (ASSOPIASTRELLE, 2006).

O setor cerâmico italiano é constituído por 228 empresas que ocupam 29.817 pessoas em 317 unidades de produção, quase inteiramente concentrado no pólo da cidade de Sassuolo (Modena), que representa, de acordo com a Assopiastrelle (2006), 80\% da produção italiana. A região de Sassuolo abriga, numa área restrita, fabricantes de cerâmicas e fornecedores de equipamentos e serviços, constituindo um dos mais desenvolvidos e conhecidos "clusters" ou Arranjo Produtivo Local (APL) 
da Europa. A proximidade de fornecedores e concorrentes e a facilidade de circulação da informação geraram um impulso único no desenvolvimento de produtos e tecnologia, tanto que a realidade de Sassuolo é objeto de estudo de economistas e sociólogos do mundo inteiro. A grande eficiência produtiva das empresas deve-se ao alto nível de pesquisa e de inovação tecnológica, seja pela qualidade do produto, seja pela gestão das plantas de produção, altamente automatizadas e otimizadas. Isso é mantido com um constante esforço em investimentos, que em 2004 alcançou os 241,5 milhões de Euro e, nos últimos anos, vem se estabilizando em $4,5 \%$ do faturamento total.

É importante observar que, nos últimos 10 anos, a produção quase dobrou, passando de $311 \mathrm{Mm}^{2}$ em 1985 a quase 600 em 2004, ao passo que o faturamento cresceu mais de 3 vezes, passando de 1,58 bilhões de Euro de 1985 a 5,33 bilhões em 2004. Isto evidencia a constante qualificação e apreciação dos produtos no mercado internacional.

A Assopiastrelle (2006) comunica os dados sobre a distribuição da produção italiana por tipologia de produto, em 2004, resumidos na Tabela 11.

Tabela 11 - Distribuição da produção italiana por tipologia de produto

\begin{tabular}{|c|c|c|c|c|c|}
\hline Tipologia de produto & monoqueima tradicional & biqueima & grés não esmaltado & grés esmaltado & outros \\
\hline$\%$ da produção total & 25,5 & 4,5 & 20,8 & 40,4 & 8,8 \\
\hline
\end{tabular}

Outra leitura dos dados estatísticos da Assopiastrelle permite identificar uma lenta, porém contínua alteração do destino das exportações italianas, com aumento dos volumes no mercado interno e em dois mercados preferenciais e mais remunerativos, Europa ocidental e América do Norte, e redução dos volumes nos mercados da Europa oriental e no "resto do mundo" (Tabela 12).

Conforme observa Beltrame (1998), os produtos italianos apresentam o melhor desempenho comercial, embora sejam os mais caros do mercado mundial. O principal fator que determina este resultado é a credibilidade ganha pela cerâmica made in Italy. Bordignon e Kaminski (2005) reportam que, no Brasil, os colorifícios desenvolvem $80 \%$ dos novos produtos com base na produção italiana. Os mesmos autores indicam, ainda, que a Itália é líder mundial de tecnologia e estética (BORDIGNON, KAMINSKI, 2006). A marca do design produzido na Itália é, 
provavelmente, a mais importante vantagem competitiva da indústria daquele país, apesar da boa qualidade dos produtos concorrentes.

Tabela 12 - Volumes e variação de vendas da produção italiana por destino

\begin{tabular}{|l|c|c|c|c|}
\hline \multirow{2}{*}{ VENDAS } & Base 2003 & \multicolumn{3}{|c|}{ Variação \% } \\
\cline { 3 - 5 } & & $\mathbf{2 0 0 4}$ & $\mathbf{2 0 0 5}$ & $\mathbf{2 0 0 6}$ \\
\hline Itália & 170 & $+1,3$ & $+0,9$ & $+0,2$ \\
\hline Europa ocidental & 211 & $+1,1$ & $+1,8$ & $+1,3$ \\
\hline Europa oriental & 65 & $-5,4$ & $-0,6$ & $-0,8$ \\
\hline América do Norte & 79 & $+5,2$ & $+2,5$ & $+1,1$ \\
\hline “Resto do mundo" & 51 & $-6,2$ & $-1,1$ & $-0,4$ \\
\hline Total exportação & 418 & 0,0 & $+1,3$ & $+0,8$ \\
\hline Total & 588 & $+0,4$ & $+1,2$ & $+0,6$ \\
\hline Produção & 603 & $-0,3$ & $+1,2$ & $+0,6$ \\
\hline
\end{tabular}

(1) Volumes em $\mathrm{Mm}^{2}$.

\subsection{O mercado brasileiro}

A indústria cerâmica nacional, em 2000, era constituída por 127 empresas com 23.000 empregos diretos e 160.000 indiretos, movimentando 2,3 bilhões de Reais (ARAÚJO; ROMACHELLI; MARTINS, 2001a, b).

Em 2004, o mercado brasileiro de cerâmica ocupava a $4^{a}$ posição no mundo, com uma produção $566 \mathrm{Mm}^{2}$, fabricada por 94 empresas produtoras, num total de 117 plantas e uma capacidade produtiva instalada de $622 \mathrm{Mm}^{2}$. O setor gera 25.486 postos de trabalho direto e 250.000 indiretos (ANFACER, 2006).

Ao mercado interno, que é o segundo maior mercado consumidor mundial em volume, é destinado $78 \%$ da produção. As exportações alcançam a meta de 125,8 $\mathrm{Mm}^{2}$, destinados a 139 países, num valor de 342 milhões de US\$, valores FOB. $O$ maior importador de produtos brasileiros é os EUA, com totais $36,7 \mathrm{Mm}^{2}$.

Dados referentes a 2005 (JORNAL PÓLO CERÂMICO, 2006) indicam que as exportações subiram, em valor, para 376 milhões de US\$, embora reduzindo as 
quantidades para 113,8 $\mathrm{Mm}^{2}$. A forte valorização do Real frente ao dólar e a concorrência da China são os principais fatores que reduziram o desempenho internacional.

A distribuição da produção por tipologia de produto é resumida na Tabela 13; o destino das exportações é relatado na Tabela 14.

Tabela 13 - Distribuição da produção brasileira por tipologia de produto

\begin{tabular}{|l|c|c|c|c|}
\hline Uso do produto & piso & revestimento & fachada & grés porcelanado \\
\hline $\mathrm{Mm}^{2}$ & 387,0 & 150,0 & 11,0 & 18,0 \\
\hline$\%$ da produção total & 68,4 & 26,5 & 1,9 & 3,2 \\
\hline
\end{tabular}

Tabela 14 - Mercados de destino das exportações brasileiras

\begin{tabular}{|l|c|c|c|c|c|c|c|c|c|}
\hline Destino & $\begin{array}{c}\text { América } \\
\text { do Norte }\end{array}$ & $\begin{array}{c}\text { Leste } \\
\text { Europeu }\end{array}$ & Ásia & $\begin{array}{c}\text { Oriente } \\
\text { Médio }\end{array}$ & Oceania & Europa & África & $\begin{array}{c}\text { América } \\
\text { Central }\end{array}$ & $\begin{array}{c}\text { América } \\
\text { do Sul }\end{array}$ \\
\hline $\begin{array}{l}\% \text { da } \\
\text { produção }\end{array}$ & 47,07 & 0,17 & 1,14 & 1,85 & 2,00 & 6,77 & 8,31 & 16,56 & 16,14 \\
\hline
\end{tabular}

A indústria brasileira tem como principal origem as antigas fábricas de tijolos, blocos e telhas. Essas empresas, no início do século $X X$, começaram a fabricar ladrilhos hidráulicos e, posteriormente, azulejos e pastilhas de cerâmica e vidro (RIBEIRO; QUINTAL, 2001). A localização das empresas está fortemente concentrada nas regiões sul e sudeste, que constituem $92 \%$ da capacidade instalada no país. Um dos fatores mais importantes que justificam a alta concentração é a proximidade dos maiores centros consumidores.

Com um mercado interno que chegou a $421 \mathrm{Mm}^{2}$ em 2003, o Brasil é hoje o segundo maior mercado consumidor do mundo, depois da China (BOSCHI, 2004).

Até 2001, as exportações brasileiras eram pouco expressivas. A partir de então, entretanto, o crescimento do pólo de Santa Gertrudes colocou pressão sobre as empresas que trabalhavam por via úmida, forçando-as a substituir a redução da participação no mercado interno com aumento das exportações. Um dos fatores que contribuiu significativamente foi o fortalecimento do Euro em relação ao Dólar, que dificultou as vendas dos competidores Italianos e Espanhóis.

Em 2003, as exportações brasileiras alcançaram os $103 \mathrm{Mm}^{2}$, correspondentes a 19,3\% da produção. Em 2003 os Estados Unidos, o maior importador de revestimento cerâmico do mundo, consumiu $42,3 \mathrm{Mm}^{2}$. Entretanto o valor médio dos 
produtos exportados em 2002 foi de 3,93 US $\$ \mathrm{~m}^{2}$, significativamente inferior aos valores praticados pelos principais concorrentes nesse mercado: Itália e Espanha. Considerável parte desta desvalorização dos nossos produtos deve-se à falta de união e de organização do setor. A maioria das exportações é efetuada por compradores externos que buscam o produto brasileiro por causa dos preços baixos e não especificamente pelos produtos. Os produtores nacionais comparam os preços de exportação com os do mercado interno, o que gera uma venda de oportunidade circunstancial e representa um mercado extremamente volátil. $\mathrm{O}$ que falta, então, é uma política de desenvolvimento do setor e o comprometimento dos fabricantes.

As mais de 120 indústrias brasileiras de revestimento cerâmico podem ser divididas em dois grandes grupos, segundo o processo de fabricação: as de via úmida e as de via seca. De acordo com a "Análise Setorial 2003" da Anfacer (2004), só $42,4 \%$ das cerâmicas brasileiras produzem com massa atomizada.

A grande maioria das indústrias que trabalha por via seca está localizada próxima ao centro do Estado de São Paulo. Das 60 indústrias localizadas no Estado de São Paulo, 43 constituem o Pólo de Santa Gertrudes. Dados de 2003 indicam que a produção do Estado de São Paulo representa 63\% da produção brasileira e o Pólo de Santa Gertrudes, $71 \%$ da produção de São Paulo e $45 \%$ da produção brasileira.

Por outro lado, considerável parte das empresas que trabalha por via úmida está localizada no Estado de Santa Catarina, onde formam o Pólo de Criciúma. Recentemente o número de indústrias localizadas na região nordeste tem aumentado consideravelmente.

Algumas das principais vantagens competitivas que proporcionaram o surgimento e o crescimento acentuado do importante pólo regional de Santa Gertrudes, principalmente a partir da década de 90, são:

- investimentos iniciais menores e processo mais econômico que o tradicional por via úmida;

- consumo de uma única matéria prima local: as massas da maioria das indústrias de Santa Gertrudes, que trabalham por via seca, são constituídas de uma única argila (formação Corumbataí), que é praticamente uma massa pronta;

- custos de produção inferiores: estima-se que a fabricação por via seca seja aproximadamente $30 \%$ mais econômica do que a por via úmida; além disso, os produtores locais trabalham com um número de produtos consideravelmente 
menor do que usualmente encontrado nas indústrias de via úmida, reduzindo muito as paradas para troca de produto e os estoques de insumos e produtos;

- proximidade do maior pólo consumidor do Brasil;

- preocupação do público alvo (constituído pelas classes de baixa renda) mais com os preços baixos do que com a qualidade. Até então praticamente não existiam produtos com preços acessíveis para essas camadas da população.

Em um ambiente extremamente competitivo, defrontam-se duas estratégias principais de liderança: de um lado, a busca da liderança através do custo, com a fabricação de produtos "commodities", alicerçada no sistema de produção em massa, e representada pelos produtores que utilizam o sistema de moagem a seco. Do outro lado, as empresas que foram "forçadas", pela escolha do sistema de produção, a utilizar o sistema de produção flexível, determinado pela estratégia mercadológica da diferenciação, porém ao menor custo possível. Comparam-se, portanto, as indústrias que utilizam o processo de moagem a seco com aquelas que utilizam o processo de moagem a úmido (NOGUEIRA; ALVES; TORKOMIAN, 2001).

Noguerira, Alves e Torkomian (2001) realizaram uma interessante pesquisa para definir as estratégias competitivas, principalmente a estratégia de produção do setor cerâmico no Brasil. A análise baseia-se em um leque significativo de empresas de porte grande e pequeno, com produtos fabricados por via seca e por via úmida, localizadas nos dois pólos principais, de Santa Catarina e São Paulo. O estudo indica que o setor apresenta deficiências no âmbito do planejamento estratégico e da gestão de produção. As empresas mais novas, de menor porte, localizadas no pólo de Santa Gertrudes, que utilizam tecnologia de preparação de massa por via seca, tendem a adotar estratégias competitivas de liderança em custo. As alternativas de estratégia de produção se orientam para o aumento de produtividade, a racionalização da produção, a integração para trás na cadeia de suprimentos e a utilização de canais tradicionais de distribuição e vendas. Neste segmento, a tecnologia utilizada é menos sofisticada e depende mais do apoio dos fornecedores. A qualificação da mão de obra é baixa, as estruturas administrativas são pouco especializadas e os sistemas de gestão, rudimentares.

As empresas de maior porte e mais tradicionais, localizadas em Santa Catarina e que utilizam tecnologia de preparação de massa por via úmida, adotam estratégias competitivas de diferenciação, focando segmentos de mercado de alta renda. Elas 
detêm maior domínio da tecnologia no desenvolvimento de produtos e na gestão da produção e da qualidade.

No caso de Santa Gertrudes, a tendência é a profissionalização da administração e a melhoria da qualidade, com investimentos na automação de processo e no aumento da capacidade instalada. No caso de empresas operantes por via úmida, seja em Santa Catarina, seja em São Paulo, a tendência é o investimento em novas tecnologias de produto e processo, em design mais sofisticado e em integração para frente na cadeia de suprimentos, absorvendo canais de distribuição e venda. Em relação à gestão da qualidade, existem espaços para aprimoramento do controle de processo. Os mesmos autores aconselham, também, a agir nas empresas, nas associações de classe, nas universidades ou nas agências governamentais para melhorar a competitividade.

Os custos de mão de obra, inferiores aos europeus, frearam a expansão da automação, tanto que poucos fabricantes nacionais utilizam estoque pulmão ao longo da linha e nenhum adota o sistema de estoque automático do produto antes e depois da queima. Tal sistema, universalmente utilizado nas plantas de alta produtividade na Europa, permite eliminar o $3^{\circ}$ turno (noturno) e limitar a produção a 5 dias semanais, com altas economias e enorme ganho na qualidade do produto acabado. Motivo decisivo para a atual situação nacional é o poder aquisitivo dos clientes finais, pois o preço médio do produto aceito no mercado não permite realizar um revestimento de qualidade internacional.

O horizonte brasileiro foi fortemente penalizado pelas políticas de proteção da década de 80 , que geraram uma relativa tranqüilidade entre os produtores locais, beneficiando-os só temporariamente (aparentemente), por um período que acabou com a abertura dos mercados advinda com o Plano Real. A inércia gerada pelo protecionismo deixou os ceramistas brasileiros com produtos de qualidade muito abaixo dos padrões internacionais, com uma tecnologia quase obsoleta e carentes de normas técnicas e diretrizes setoriais, desprovidos de estruturas comerciais orientadas à exportação.

O setor cerâmico brasileiro, ao longo das décadas 1980-2001, de acordo com uma recente análise de Oliveira (2002), passou a maior crise entre 1982 e 1985, com a construção civil praticamente inerte. Nessa fase, o mercado foi sustentado apenas por um pequeno número de unidades habitacionais de alto luxo e pelo mercado de reformas imobiliárias. Neste período, o setor foi sensivelmente 
penalizado pela elevação do preço do petróleo e pela escassez de combustível. As empresas trabalharam com constante capacidade ociosa e com a necessidade de buscar diversificação e substituição de fontes energéticas e, ao longo de 1987, fizeram grandes investimentos acreditando que o Governo tentaria encontrar uma solução às necessidades habitacionais, o que não se realizou. $O$ setor foi penalizado, também, pela inflação, que gerou defasagem em relação a outros setores, e pelo Plano Collor, paralisando a produção como conseqüência da paralisação do mercado. Paralelamente, a flutuação do câmbio melhorou a competitividade dos ceramistas brasileiros. A partir de 1994, os efeitos positivos do Plano Real, estabilizando a moeda, reduzindo a taxa de inflação a valores próximos a zero e aumentando o poder aquisitivo do pequeno consumidor, propiciaram um crescimento quase constante das vendas. Em 1999, iniciou-se a utilização de gás natural, reduzindo os custos de produção.

Durante as décadas de 80 e 90, a produção nacional passou de 129,7 Mm², em 1980, para 452,7 $\mathrm{Mm}^{2}$ em 2000, crescendo quase $250 \%$. Com referência às exportações, no mesmo período, passaram de $6 \mathrm{Mm}^{2}$, em 1980, para 47,5 $\mathrm{Mm}^{2}$ em 2000 , crescendo quase $700 \%$, porém em ritmo oscilante. Considere-se que em 1982 e 1990 verificaram-se quedas muito sensíveis dos volumes exportados (respectivamente de $26 \%$ e $37 \%$ ), exigindo alguns anos para recuperar o patamar alcançado antes destas crises (OLIVEIRA, 2002).

O maior freio ao incremento das exportações era representado (e talvez o seja ainda hoje) pelo sistema portuário e o custo do frete, chegando a representar $30 \%$ do custo final do produto. Para participar do mercado internacional, o produto brasileiro precisou realizar sérias mudanças; a maior foi alcançar a conformidade às ISO 13006.

Ainda sobre as exportações de 2005, deve-se relatar que, por ocasião de uma recente feira de setor, componentes da alta diretoria de alguns dos maiores produtores nacionais, em conversa informal, comentaram ter registrado perdas da ordem de dezenas de milhões de Reais. A causa é a contínua revalorização do real sobre o dólar, juntamente à impossibilidade de reduzir a exportação devendo respeitar acordos comerciais de longo prazo definidos em períodos anteriores à alteração do câmbio.

A principal e mais atual meta do setor cerâmico brasileiro, com referência às exportações, é a diminuição da participação nos mercados americano e argentino, 
que representam, juntos, quase metade do mercado consumidor externo e a implementação de novas estratégias de marketing, concentrando os esforços comerciais em outros mercados, diversificando países e faixas de consumidores (OLIVEIRA, 2002).

No presente contexto de comparação dos mercados italiano e brasileiro, é importante ressaltar os valores unitários de produtos cerâmicos no mercado internacional, que melhor podem caracterizar as duas realidades (ibidem), como indicado na Tabela 15.

Tabela 15 - Preço unitário dos produtos cerâmicos (US\$FOB / t)

\begin{tabular}{|l|c|c|c|}
\hline Ano de referência & Itália & Brasil & Valor unitário médio mundial \\
\hline 1980 & 975 & 656 & 717 \\
\hline 1985 & 472 & 430 & 435 \\
\hline 1991 & 731 & 502 & 600 \\
\hline 1995 & 625 & 378 & 472 \\
\hline 1998 & 524 & 323 & 385 \\
\hline
\end{tabular}

Valores deflacionados pelo IPC dos EUA (base: média de 1982 a $1984=100$ )

\subsection{Síntese}

A análise dos dados históricos e atuais permite resumir em poucos pontos a comparação entre a cerâmica brasileira e a italiana.

A Itália é líder mundial do setor e exporta mais de $70 \%$ da produção que é concentrada em um único cluster (Sassuolo) responsável por $80 \%$ do volume total. O setor é caracterizado por alta taxa de investimento ( $4,5 \%$ do faturamento) destinado a tecnologia de produção e de acabamento. O investimento em tecnologia gera inovação e modernização do parque industrial, focando a automação mais avançada e integrada, e a redução do impacto ambiental. No caso do acabamento, os investimentos se destinam a pesquisa de novos métodos e materiais para a decoração do produto, visando a melhorar a qualidade e a estética. A produção tem crescimento constante e o faturamento cresce mais que linearmente com a produção 
(em 10 anos a produção dobrou e o faturamento multiplicou por 3). Os produtos são os mais caros do mundo, destacando-se por inovação tecnológica e artística. A exportação privilegia a Europa e a América do Norte, com tendência a restringir o leque dos mercados de destino. Com referência à tecnologia de produção, $100 \%$ das empresas italianas produzem pelo processo "a úmido".

O Brasil é, mantendo a exclusão da China, o $3^{\circ}$ produtor mundial; $78 \%$ da produção é destinada ao consumo interno, representando o segundo maior mercado consumidor. A produção está alcançando a italiana (apenas $6 \%$ menor) e é realizada num número menor de instalações (quase a metade) e com menor número de empregados (85\%), o que, aparentemente, indicaria uma economia de escala maior. $\mathrm{Na}$ realidade, esta diferença de produtividade deve ser atribuída à tipologia da produção. O grés porcelanato é um produto que, embora não exija incidência maior de mão de obra, é responsável por uma produtividade consideravelmente menor que os produtos tradicionais; por outro lado carrega um valor agregado muito superior ao da cerâmica tradicional. $\mathrm{Na}$ Itália a produção se foca no grés porcelanato, que entre esmaltado e não esmaltado representa mais de $65 \%$ da produção total. No Brasil a produção de grés é responsável por apenas $3 \%$ do total. Considerando estas informações, é possível afirmar que a produtividade específica, por tipologia de produto, ainda é menor no Brasil, sendo comparável com a européia apenas no caso das instalações produtivas mais recentes.

A exportação brasileira privilegia o hemisfério oeste, particularmente a América do Norte. O setor é caracterizado por baixo investimento e parque industrial obsoleto, com automação limitada. A localização dos produtores é concentrada em dois pólos (sul e sudeste) e está iniciando o desenvolvimento de um terceiro (nordeste). $O$ valor médio do produto brasileiro é decididamente inferior ao italiano, com $2,72 \mathrm{US} \$ / \mathrm{m}^{2}$ do produto exportado contra $11 \mathrm{US} \$ / \mathrm{m}^{2}$ do italiano, calculado no volume integral de venda. Apenas $42 \%$ do produto brasileiro é obtido pelo processo "a úmido".

A tabela 16 agrega alguns dados gerais de produção e valores.

A Figura 1 permite a localização geográfica dos centros de produção de cerâmica para revestimento no Brasil. 
Tabela 16 - Resumo comparativo dos dados de produção e venda - ano 2004

\begin{tabular}{|c|c|c|c|}
\hline \multicolumn{2}{|l|}{ PARÂMETRO } & ITÁLIA & BRASIL \\
\hline \multirow[t]{2}{*}{ Produção total } & {$\left[\mathrm{Mm}^{2}\right]$} & 589,20 & 566,00 \\
\hline & $\%$ mundial & $9,00 \%$ & $8,60 \%$ \\
\hline \multirow[t]{2}{*}{ Venda total } & {$\left[\mathrm{Mm}^{2}\right]$} & 601,00 & 574,00 \\
\hline & bi US\$ ${ }^{1}$ & 6,48 & $1,56^{(2)}$ \\
\hline \multirow[t]{3}{*}{ Venda interna } & {$\left[\mathrm{Mm}^{2}\right]$} & 188,50 & 448,00 \\
\hline & $\%$ da prod. tot & $30,00 \%$ & $78,00 \%$ \\
\hline & bi US\$ ${ }^{1}$ & $1,82^{(2)}$ & $1,16^{(2)}$ \\
\hline \multirow[t]{3}{*}{ Exportação } & {$\left[\mathrm{Mm}^{2}\right]$} & 412,50 & 125,80 \\
\hline & $\%$ da prod. tot & $70,00 \%$ & $22,00 \%$ \\
\hline & bi US\$ 1 & $4,66^{(2)}$ & 0,34 \\
\hline \multirow[t]{3}{*}{ Empresas } & $\mathrm{N}^{\circ}$ & 228 & 94 \\
\hline & Unidades produção & 317 & 117 \\
\hline & empregados & 29.817 & 25.486 \\
\hline \multirow[t]{2}{*}{ Produtividade específica } & mi US\$ / empregado & $0,22^{(2)}$ & $0,06^{(2)}$ \\
\hline & $\mathrm{m}^{2} /$ empregado & $19.760^{(2)}$ & $22.202^{(2)}$ \\
\hline Preço médio do vendido & US $\$ / \mathrm{m}^{2}$ & 11,00 & $2,72^{(2)}$ \\
\hline
\end{tabular}

(1): valor em Euro, convertido com taxa de câmbio média do mês de junho 2004: 1 Euro = 1,2155 US\$ (Banco Central, 2006).

(2): dados estimados pelo autor, na ausência de dados oficiais.

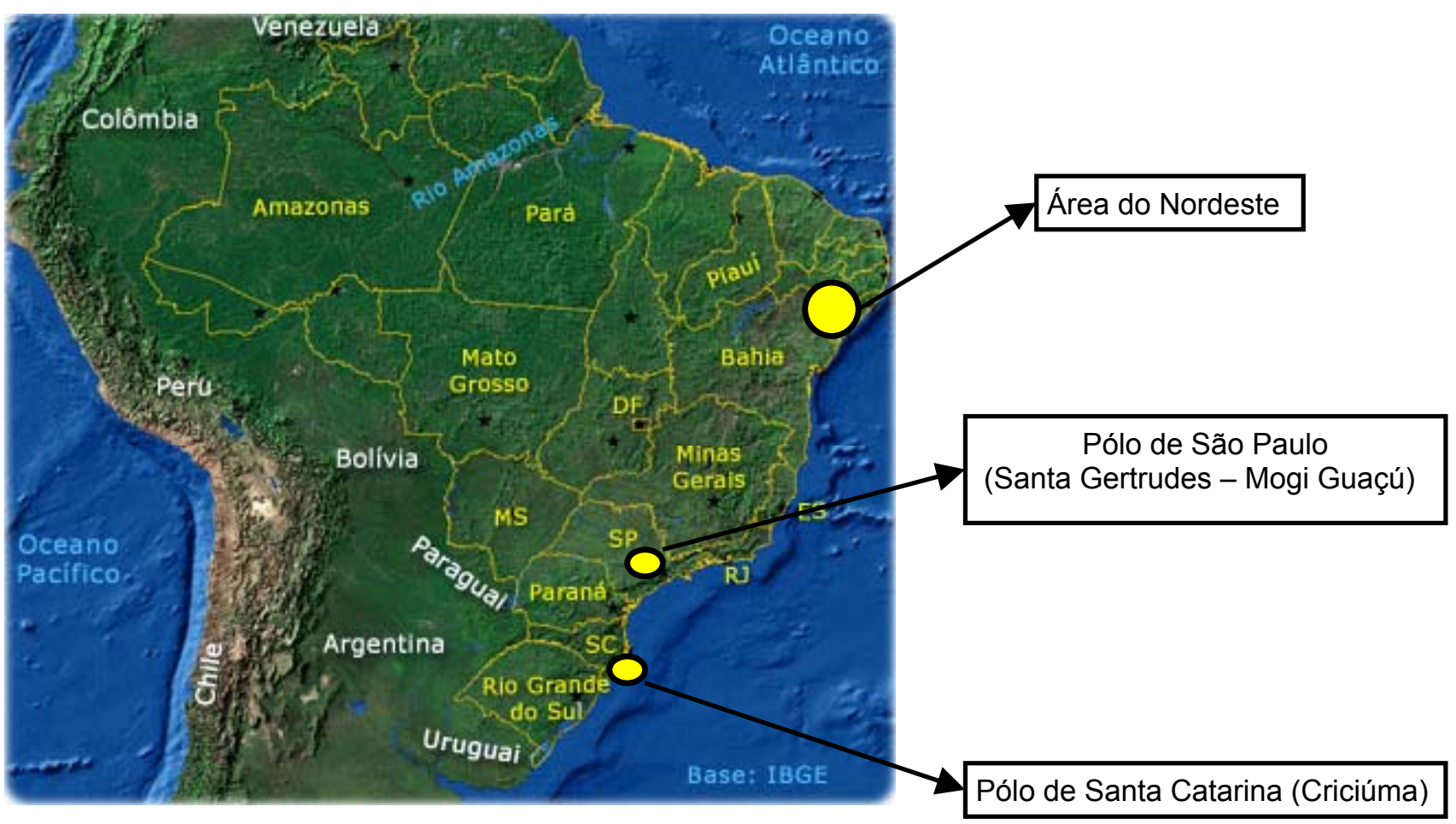

Adaptado de: Guia geográfico, 2007.

Figura 1 - Localização dos pólos cerâmicos 


\section{O PROCESSO DE PRODUÇÃO}

\subsection{O processo geral de monoqueima}

No processo de produção de peças cerâmicas por monoqueima, a aplicação do esmalte é feita no suporte "verde", ou cru, chamado "biscoito". A queima sucessiva é simultânea no biscoito e no esmalte (VENTURI, 1986). Desde que a cerâmica começou a assumir proporções industriais, o conceito de queima única foi preferido, quando possível. No caso da porcelana para uso doméstico (apesar de secar o biscoito a alta temperatura, $900^{\circ} \mathrm{C}$, apenas para poder manusear a peça) dos isoladores elétricos de porcelana, dos sanitários e de outros produtos, as peças são queimadas uma única vez. A presente dissertação se refere, porém, ao processo de monoqueima relativo à fabricação de peças esmaltadas para pisos e paredes, o qual efetivamente, constitui-se como uma tecnologia nova, sendo que as primeiras plantas industriais de grande dimensão datam do início dos anos setenta.

Os materiais produzidos com este sistema podem ser divididos basicamente em duas categorias: materiais greificados (grés vermelho), aptos para uso externo e em condições de baixa temperatura, cujas características tecnológicas são predominantes, e materiais porosos, aptos a serem utilizados em ambientes internos, como piso e revestimento de parede, cujas características estéticas e decorativas são preponderantes (VECCHI, 1977). O processo se contrapõe ao mais tradicional de "biqueima", que prevê queimar as peças duas vezes, a primeira reservada exclusivamente ao suporte, a segunda destinada à "maturação" do esmalte aplicado entre as duas fases de queima. A monoqueima, portanto, prevê uma queima única para a sinterização do suporte e a maturação do esmalte (VENTURI, 1986).

Inicialmente, a monoqueima representou uma verdadeira inovação. A biqueima permite queimar a produção em "massa", isto é, alimentando o forno com várias peças empilhadas, apoiadas em estruturas que mantêm uma distância mínima entre elas, apenas para não danificar o esmalte, sendo possível, também, queimar qualquer tipo de massa cerâmica. A monoqueima, por processar um suporte "verde" e pela tendência de produzir um material altamente greificado (com proeminente 
fase líquida), exigia a passagem no forno das peças sobre suportes individuais (placas refratárias), em simples camada. A escolha da baixa porosidade resídua da produção era ditada pela baixa homogeneidade térmica dos fornos, que garantia estabilidade dimensional do produto apenas com a porosidade próxima de zero (produto altamente greificado). Esta tecnologia favorecia o uso de massa vermelha em comparação à branca ou semibranca, pela menor característica refratária. Nasceram assim os fornos monocamada, com vários canais independentes, com ciclo rápido, de até 150 minutos. Dessa tipologia de fornos, derivam os modernos fornos rápidos de rolos, hoje universalmente utilizados pela monoqueima. A tipologia de forno de rolos permitiu ampliar as tipologias de produtos, aumentando suas dimensões e características. Hoje a Espanha é o maior produtor do mundo de "monoporosa", isto é, um produto de média ou alta porosidade, para revestimento (azulejo), obtido por monoqueima.

A partir dos anos 70, então, passou-se do processo de queima lenta ao de queima rápida e conseqüentemente todas as fases do processo foram repensadas em função desta grande inovação que determinou perspectivas tecnológicas antes impensáveis. As dimensões dos fornos aumentaram, os sistemas de combustão e de controle melhoraram, permitindo uma distribuição térmica otimizada em relação aos materiais, especialmente nas áreas críticas da curva de queima.

A dinamicidade do setor cerâmico foi determinante ao favorecer a contínua evolução dos processos de produção. Ao longo dos anos 70 se assistiu à transformação tecnológica das plantas de produção, passando dos processos tradicionais em forno de túnel aos modernos sistemas que adotam forno de rolos, com ciclos rápidos de queima. A adoção destas novas tecnologias exigiu novos layouts e o elevado grau de automação permitiu uma forte compressão dos custos industriais. Conseqüentemente, nos anos 80 , verificou-se a evolução dos processos de produção, nas diferentes fases, por meio de difusão da moagem a úmido descontínua, introdução do processo de atomização ${ }^{9}$ da barbotina $^{10}$, difusão das prensas hidráulicas, adoção de secadores rápidos e difusão de fornos de rolos. 0

\footnotetext{
9 Atomização: processo para obter a evaporação da água contida numa barbotina, até valores residuais de 4-7 \%; consiste na injeção em alta pressão (2,5-3,0 MPa) e nebulização da barbotina do lado inferior do atomizador, em contracorrente com um fluxo de ar quente. A barbotina é assim transformada em aglomerado de pó seco, de granulometria e umidade controlada. Venturi (1986).

${ }_{10}$ Barbotina: dispersão da massa cerâmica moída em água; produto final da moagem a úmido. Facilita a homogeneização de matérias primas extremamente diferentes. Venturi (1986).
} 
uso da moagem contínua está se firmando, cada vez mais, também para plantas de pequena e média dimensão.

Nos anos 90, assiste-se à consolidação dos processos de produção da monoporosa e da biqueima rápida, permitindo a redução dos custos industriais.

São evidentes, então, os efeitos da rápida evolução tecnológica ao longo dos últimos 30 anos, que podem ser resumidos em aumento da produtividade por pessoa, diminuição da área ocupada pela planta e redução dos custos industriais (SACMI, 2003).

A adoção, cada vez mais difundida, de dispositivos eletrônicos avançados permitiu automatizar completamente o processo, com particular evidência no que se refere à movimentação do produto. Ao longo da linha, o produto é deslocado com sofisticados sistemas de transporte contínuo, de rolo ou correia. Devido à alta produtividade dos equipamentos, é necessário dispor em vários pontos do processo de "acumuladores" de estoques, com função de segurança. Caso algum problema se verifique numa seção da linha, os dispositivos de acúmulo permitem realizar as intervenções emergenciais necessárias, sem provocar parada às seções que precedem e seguem. O último e sofisticado desenvolvimento dos sistemas de movimentação é representado pelo uso de equipamentos de guia laser para estocagem e movimentação do produto verde e queimado. Trata-se de verdadeiros sistemas logísticos, mais adiante descritos com detalhes.

O sucesso da tecnologia de monoqueima se deve a vários fatores, como a rapidez do ciclo de queima, que permite sensível economia (em tempo, espaço, energia, mão de obra), o incremento das características mecânicas do produto acabado, a resultante simplicidade dos sistemas de esmaltação, a possibilidade de produção de grandes formatos e de utilização de automação extremamente avançada.

$\mathrm{Na}$ figura 2 é exposto o fluxograma do processo geral de produção de monoqueima. Na descrição que segue, são sinteticamente descritas as fases e as operações características que compõem o processo geral de monoqueima, com referência à figura 1 (BORDIGNON, 2004). 


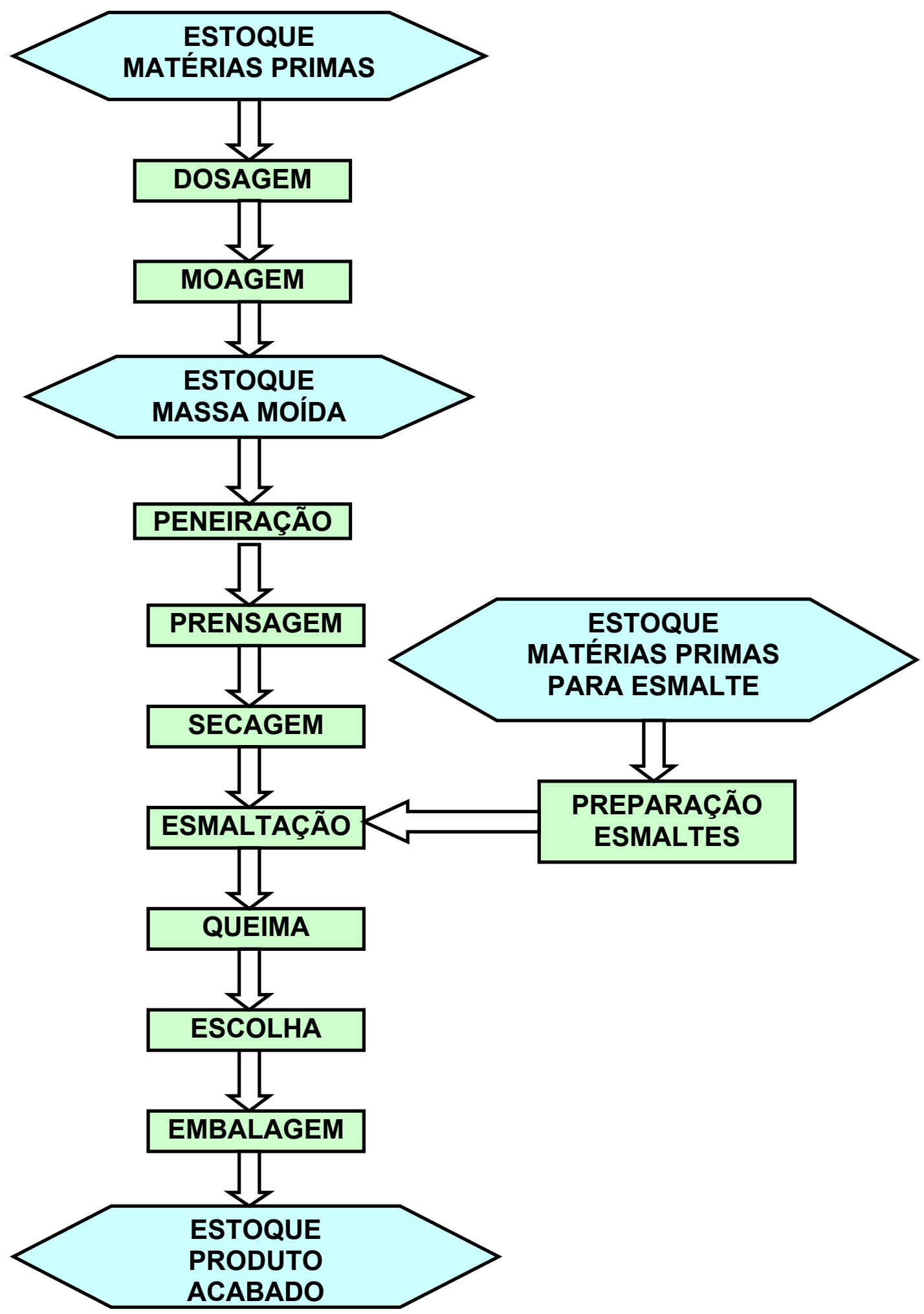

Figura 2 - Fluxograma do processo genérico de produção de monoqueima 
O processo inicia-se com o recebimento das matérias primas, que, no caso das argilas, devem ser mantidas no estoque por tempo determinado, para homogeneizar a umidade.

Juntamente à natureza química e às associações mineralógicas das matérias primas, as características finas do produto dependem fortemente dos parâmetros tecnológicos adotados ao longo do processo de fabricação. Alguns comentários serão estendidos, ao longo do texto, evidenciando os aspectos mais importantes.

Prossegue com a dosagem, quando diferentes matérias primas são pesadas nas proporções determinadas pela formulação do produto. Esta fase pode ser realizada com pesagem descontínua ou contínua e pode ser realizada com equipamentos de diferentes níveis de automação; no caso descontínuo, podem ser usados sistemas mecânicos tradicionais. Ao contrário, para alimentar moinhos contínuos, é necessário dispor de esteiras de pesagem contínua, controladas por microprocessador. A massa dosada pode ser estocada temporariamente em silos de pré-carga dos moinhos (SACMI, 2003).

Em seguida, as matérias primas são encaminhadas à fase de moagem, que pode ser a úmido ou a seco e com processo contínuo ou descontínuo. A moagem tem como objetivo a redução dimensional e a homogeneização das matérias primas, até a obtenção de características finais constantes em termo de composição e de granulometria. É uma fase importante e delicada, pois o grau de moagem influencia a estabilidade dimensional e a porosidade do produto final (BORDIGNON, 2004).

No caso da monoporosa, o grau de moagem das matérias primas pode influenciar também a temperatura final de eliminação de gases da massa ou a reatividade dos componentes durante a queima. No caso de massa greificada, influi sobre os valores de encolhimento e porosidade residual. Em ambos os casos, altera sensivelmente as características mecânicas finais do produto (SACMI, 2003).

Com base nas características das matérias primas, os fatores principais que condicionam o processo são as dimensões iniciais, a dureza, a estrutura física, o conteúdo de água, o comportamento reológico e as impurezas dos minerais. Outro fator determinante é a granulometria final do pó a ser obtido e as considerações de economia e eficiência do processo.

No caso descontínuo, dois são os momentos de interrupção do processo, a carga e a descarga do moinho. O processo de moagem contínua está se difundindo amplamente, em virtude das vantagens que apresenta, em termo de maior 
constância das características do pó, aumento da densidade, melhores características reológicas, maior racionalidade na planta e sensível economia direta (mão de obra) e indireta (energia requerida pela moagem).

No caso da moagem a úmido, pode ser realizada a dissolução prévia de parte da argila (geralmente a fração mais fina e de maior plasticidade), produzindo uma suspensão argilosa que é colocada no moinho ou diretamente na barbotina em saída.

No caso do porcelanato, a cor da massa base pode ser obtida adicionando, de forma descontínua, "xaropes"11 concentrados, cuja moagem é realizada em moinhos específicos. No processo de moagem a úmido é necessário secar a barbotina. Esta fase é realizada com a atomização, que efetua a evaporação da água e realiza a formação de partículas esferoidais. A massa moída é estocada até prosseguir o ciclo.

O dimensionamento da planta de atomização, no caso do porcelanato, depende da tipologia de produto e do número de cores requeridas. Embora o processo de atomização seja conceitualmente o mesmo para todo tipo de produto cerâmico, a complexidade do conjunto de pó necessário define número e potencialidade de tanques, silos e até atomizadores a serem instalados. Prevendo a produção de regranulado, a configuração da planta é ainda mais complexa.

$\mathrm{Na}$ fase sucessiva, após uma peneiração de controle, a massa moída alimenta a prensa, que realiza a compactação e a conformação do suporte. A prensagem é uma fase extremamente importante do processo. O objetivo é a obtenção da máxima densidade da massa verde, para não gerar defeitos na queima (esfoliação, falta de resistência mecânica, auréola ${ }^{12}$, coração negro ${ }^{13}$, densidade não uniforme). As prensas hidráulicas atualmente utilizadas representam o melhor compromisso entre características do produto, confiabilidade mecânica e economia energética. A operação é realizada em prensas hidráulicas de alta potência (até 7.000 t) e a pressão específica, na massa, varia entre 20 e $30 \mathrm{MPa}$; no caso de massas vermelhas e mais plásticas pode descer a valores de $15 \mathrm{MPa}$. No caso do grés

\footnotetext{
${ }_{11}^{11}$ Xarope concentrado é constituído de barbotina colorida com alta concentração de pigmentos.

12 Auréola: defeito devido a alta quantidade de pó fino na massa, gerado pelo movimento do ar deslocado pelo punção móvel durante o fechamento do estampo, que arrasta o pó fino adensando-o nas bordas (BIFFI, 2000).

${ }^{13}$ Coração negro: defeito devido à incompleta oxidação na queima de substâncias orgânicas presentes na massa, constituído por uma mancha escura na parte interna das placas (núcleo), (BIFFI, 2000).
} 
porcelanato, a compactação da massa é maior, sendo necessário utilizar pressões específicas de 35 até 45 MPa.

O produto "verde" deve perder a umidade residual, o que se realiza na secagem, cujo ciclo deve garantir a eliminação da umidade residual da massa (4-7\%), o controle da estabilidade dimensional e o incremento da resistência mecânica do material, necessário para enfrentar as solicitações da decoração serigráfica. Utilizam-se secadores verticais, com o produto colocado em estruturas de suporte, ou horizontais, mono ou multicamada, sobre rolos. Com o uso de secadores verticais, o ciclo é aproximadamente de 35 a 70 minutos; com a tipologia horizontal, o ciclo tem duração de 6 a 20 minutos.

Segue a esmaltação. A decoração do produto é obtida por deposição de esmaltes. A tipologia do produto final define o tipo e o número das aplicações na linha de esmaltação e o estado físico dos esmaltes, que podem ser suspensões em água ou pastas misturadas com veículos serigráficos ou secas, com colas e outros aditivos. As exigências são as mais variadas, de 4 ou 5 até 25 ou mais aplicações, depositando de $300 \mathrm{~g} / \mathrm{m}^{2}$ até $3 \mathrm{~kg} / \mathrm{m}^{2}$ de esmalte. A linha de esmaltação completa é obtida compondo, na seqüência estabelecida, módulos padrão, cada um com o próprio sistema de transporte e com suas unidades de aplicação. Variáveis de processo importantes são as características reológicas dos esmaltes, o correto funcionamento das máquinas decoradoras, as características do produto após a secagem, o peneiramento dos esmaltes e a eliminação de contaminantes cromóforos (ferro).

A extrema automação que regula o processo de produção em todas as fases de trabalho entra com dificuldade na linha de esmaltação, na qual o rolo dos operadores continua prioritário e fundamental.

Com referência ao processo do grés porcelanato, se antes não era realizada a esmaltação das peças, hoje a sofisticação dos produtos, exigida pelo mercado, impõe a presença de linhas com algum grau de complexidade. A tecnologia ligada ao uso de sais solúveis ou outros tipos de esmaltes é relativamente recente e, em alguns casos, sofisticada. O comprimento das linhas pode variar de 30 até $120 \mathrm{~m}$.

Entre os fatores mais importantes desta fase do processo, destacam-se a temperatura do suporte, que influi sobre a difusão da solução salina e o método de aplicação, pois a quantidade de sais cromóforos ou esmaltes a serem aplicados 
depende do sistema aplicador, determinando a intensidade da cor e a quantidade de solvente utilizado, que altera a profundidade de impregnação.

A estabilização do sal após a aplicação pode ser feita naturalmente (no ambiente) ou com uso de máquinas térmicas (pequenos secadores de linha).

A fase sucessiva é a queima, operação fundamental da produção cerâmica, que permite o desenvolvimento de todas as reações que determinam a aquisição das características tecnológicas e estéticas desejadas, com a sinterização do suporte e a maturação do esmalte (VENTURI, 1986). A definição dos parâmetros de queima (curva térmica) é fundamental para o correto desenvolvimento do complexo quadro de reações químico-físicas que se realizam. É importante observar que os resultados dependem da natureza químico-física da massa, do grau de moagem, da densidade aparente do suporte prensado e da temperatura máxima de queima. A análise de tais parâmetros não pode ser feita separadamente, mas considerando as respectivas interações e os efeitos sinérgicos obtidos pela variação simultânea de vários deles.

O processo hoje mais utilizado é a queima rápida, monocamada e sobre rolos, em fornos rápidos de passagem (BORDIGNON, 2004). Os ciclos de queima atualmente usados variam de 35 a 60 minutos e as temperaturas máximas podem oscilar entre $1.080^{\circ} \mathrm{C}$ e $1.220^{\circ} \mathrm{C}$. No caso do grés porcelanato, variam de $45 \mathrm{~min}$., para formato e espessura modesta, a $90 \mathrm{~min}$., necessários para formatos de grande dimensão e espessura elevada, e até a 120-160 min., no caso das dimensões máximas hoje produzidas $(1 \times 2 \mathrm{~m})$. As temperaturas máximas variam de $1.180^{\circ} \mathrm{C}$ a $1.270^{\circ} \mathrm{C}$, dependendo das características da massa, do grau de moagem da barbotina e da compactação na fase de prensagem (SACMI, 2003).

São identificadas as fases de pré-aquecimento, até $800^{\circ} \mathrm{C}$, temperatura em que se verifica a destruição dos materiais argilosos; de aquecimento, até $900^{\circ} \mathrm{C}$, em que os carbonatos são decompostos e o $\mathrm{CO}_{2}$ é eliminado; de queima, até $1.100^{\circ} \mathrm{C}$, em que se realizam as reações de síntese dos óxidos com as fases amorfas e verificase a neoformação de compostos, que são fundamentais para definir as características mecânicas do produto; de sinterização, até a temperatura máxima (próxima a $1.180^{\circ} \mathrm{C}$ para monoporosa e $1.270^{\circ} \mathrm{C}$ para grés), em que são completadas a sinterização do suporte e a fusão do esmalte; de resfriamento rápido, até $600^{\circ} \mathrm{C}$, para obter a solidificação do esmalte; de resfriamento lento, até $200^{\circ} \mathrm{C}$, para redistribuir as tensões internas devidas à transformação do quartzo livre. 
As características de planicidade são controladas gerenciando pequenos gradientes de temperatura entre as faces superiores e inferiores do produto.

O processo de produção termina com a escolha e a embalagem. A escolha é realizada em duas fases, uma relativa a cor e tonalidade do esmalte e uma relativa a parâmetros dimensionais. O controle das características estéticas do produto final e sua classificação é realizado manualmente, por operadores especificamente treinados. Nesta fase, o produto é deslocado sobre esteira e passa na frente do operador que compara o produto com uma ou mais amostras de referência postas numa mesa ao lado da esteira; o operador marca com tinta especial as peças defeituosas ou com classificação especial. $\mathrm{Na}$ fase seguinte, o equipamento que verifica as características dimensionais do produto reconhece as marcas do operador e separa as peças de acordo com a classificação definida. A seleção dimensional dos produtos é realizada em máquinas automáticas, com equipamentos eletrônicos que verificam o calibre e a planicidade das superfícies, classificando o produto automaticamente e separando-o para a embalagem.

Embora não tenha intervenção nas características do produto, a escolha é uma fase muito delicada do ciclo de produção, pelo que tange à qualidade final do produto. É importante ressaltar que a seleção do produto, com respeito à tonalidade da decoração e a eventuais defeitos estéticos, é manual e depende exclusivamente da habilidade e atenção do operador e das condições luminotécnicas do ambiente.

Alguns fabricantes europeus, recentemente desenvolveram sofisticados equipamentos óticos de escolha em função da tonalidade do produto. Em consideração da alta produtividade, do grande número de variantes de formatos desenhos e cores dos produtos, das pequenas diferenças de tonalidade a serem detectadas, os resultados ainda não alcançaram a confiabilidade necessária, inviabilizando a difusão deste interessante tipo de equipamento.

O processo de embalagem é também automatizado e no caso de linhas de alta produção, a automação se estende até a formação da paleta e seu revestimento com filme plástico extensível ou termo-encolhível (BORDIGNON, 2004).

Algumas linhas de produtos de grés porcelanato requerem uma ulterior fase de processo: o polimento e a esquadrejatura, ou retífica dimensional. A elevada compactação do grés permite obter, com o polimento, superfícies especulares, com grande ganho estético. A retífica das bordas permite a colocação final das peças 
lado a lado, dispensando a utilização de rejunte, criando assim pisos contínuos com resultados estéticos de grande efeito visual.

A fase de polimento se caracteriza mais como um pequeno processo separado, prevendo as fases de polimento próprio e o de esquadrejatura e "bisellatura"14 $\mathrm{O}$ polimento, geralmente a úmido, é realizado exclusivamente sobre produto de $1^{\mathrm{a}}$ escolha e inclui as subfases de calibragem da peça, desbaste, primeiro polimento e polimento final.

A esquadrejatura consiste de uma calibragem fina do produto e deixa todas as peças com tamanho único.

A bisellatura realiza um chanfre nas bordas (SACMI, 2003).

Com respeito à produção do grés porcelanato, se comparada à de outras tipologias de produtos cerâmicos, salienta-se a introdução de alguns aspectos tecnológicos e de planta peculiares. Trata-se do uso de barbotinas coloridas (comum a todas as produções de grés porcelanato) da dosagem e mistura de pó colorido (exigido para a realização de granitos) da realização de granulados, da mistura com pó de diferente densidade para a realização dos macro-granitos, da distribuição de pó colorido na fase de prensagem, na produção dos "variegati", da formulação, aplicação e secagem de soluções cromóforas para os produtos decorados.

\subsection{A produção de monoqueima na Itália}

A configuração do processo produtivo pode apresentar diferentes níveis de sofisticação, dependendo do grau de automação e do tipo de controle adotado.

A Figura 3 representa o fluxograma do processo de monoqueima universalmente adotado na Itália.

Os principais fatores a serem examinados para definir o grau de sofisticação da planta são, geralmente, o nível tecnológico e a cultura local, as dimensões da planta e a sua flexibilidade (SACMI, 2004).

$\mathrm{Na}$ Itália, o processo de produção é altamente consolidado e a quase totalidade dos produtores utiliza o processo de moagem a úmido e o estoque pré/pós queima, além de um grau de automação muito elevado.

\footnotetext{
${ }^{14}$ bisellatura: termo técnico, de origem italiana, que indica a execução de um chanfre nas bordas das peças cerâmicas.
} 


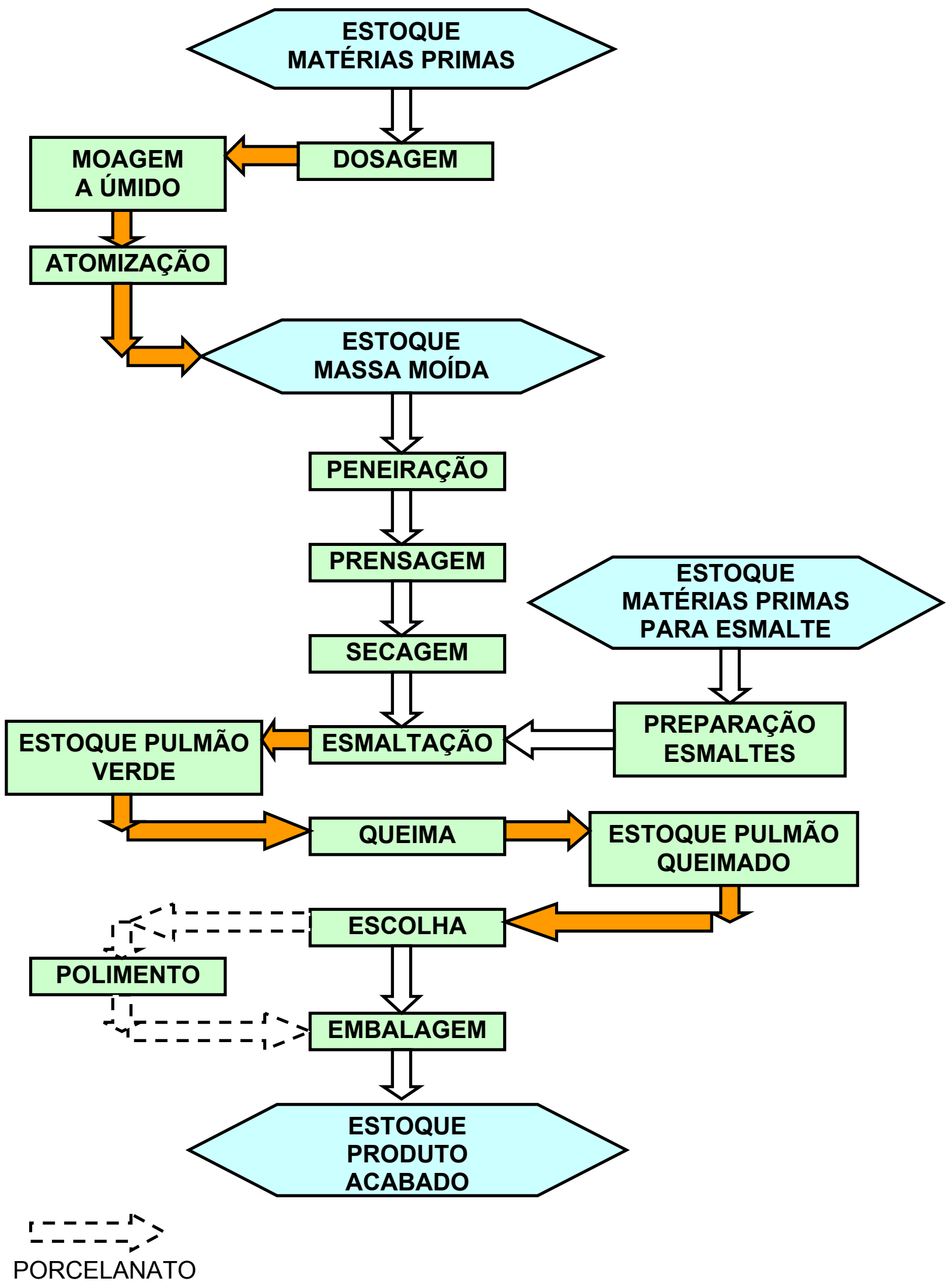

Figura 3 - Fluxograma do processo de produção de monoqueima na Itália 
O uso de estoque pré/pós queima permite, ao longo do dia (em dois turnos), a acumulação de uma quantidade de produto suficiente para alimentar o forno de queima no período noturno ( $3^{\circ}$ turno) e nos finais de semana, quando todos os outros equipamentos, à exceção do forno, permanecem inativos. Paralelamente, nos mesmos períodos de inatividade, na saída do forno é criado um estoque de produto queimado que, ao longo dos períodos normais de trabalho, é processado pela secção final de escolha e embalagem. As conseqüências deste tipo de escolha tecnológica são de grande relevância.

A moagem a úmido permite a obtenção de um produto com características técnicas muito superiores às do produto moído a seco.

A maior limitação para obter uma satisfatória constância no controle de qualidade do produto acabado, pelo que se refere a cores e tonalidades, é representada pelas condições do ambiente de trabalho. A escolha é efetuada por operadores oportunamente treinados, que comparam visualmente o produto que passa na linha de produção com algumas amostras padrão. É evidente que a capacidade objetiva de julgamento do operador depende de muitos fatores, como tempo de trabalho contínuo, disposição física e, principalmente, das condições ambientais, em termo de iluminação. Por iluminação se entende o significado mais completo em termo de iluminotécnica, o que envolve não apenas o nível luminoso da mesa de trabalho, mas as características de temperatura-cor, reflexão e outros parâmetros próprios do material. Os parâmetros de iluminação da mesa dependem fortemente das condições do ambiente externo, particularmente pela influência da iluminação natural. É evidente que as condições de trabalho e, conseqüentemente, a capacidade de julgamento do operador muda do dia para a noite. A eliminação do trabalho de escolha no período noturno incrementa muito a constância da qualidade do processo de escolha do produto a ser embalado.

A última análise de mercado da ASSOPIASTRELLE (2006) releva que a produção de biqueima, na Itália, é responsável por aproximadamente $8 \%$ da produção total de cerâmica para revestimento, baseada na maior facilidade desse processo em aceitar tipologia de decoração altamente sofisticada. Trata-se, portanto, de nichos específicos de mercado. 


\subsection{A produção de monoqueima no Brasil}

No Brasil o processo de monoqueima também é preponderante. Ainda existem instaladas e operativas algumas linhas de biqueima, limitada à produção de azulejo de pequeno formato, em unidades obsoletas e destinadas a serem desativadas a curto prazo, quando serão substituídas por linhas modernas de monoqueima.

A Figura 4 representa o fluxograma geral do processo de monoqueima adotado no Brasil.

Como antes relatado, a maioria dos fabricantes (58\%) adotou o processo a seco. A escolha pode ser justificada pelas características do mercado e por conveniência dos fabricantes.

Do ponto de vista tecnológico, o tipo de processo que utiliza a moagem a seco e a re-granulação do pó é utilizável na produção de revestimento e pode ser adotado na biqueima, quando se pode utilizar uma composição de massa muito rica em materiais argilosos ou, melhor, quando se usam materiais com características morfológicas similares. Por outro lado, menos freqüente e de qualquer forma dificultada, resulta a produção de monoporosa em linhas que integram este tipo de moagem (SACMI, 2003). É exatamente o que ocorreu no pólo de Santa Gertrudes, onde há disponibilidade de matéria prima uniforme e com característica de preponderante argilosa, porém utilizada na fabricação de produtos de baixa densidade (monoporosa).

Ribeiro e Quintal (2001, pp. 14-15) ressaltam a diferente qualidade dos produtos obtidos por moagem a úmido ou a seco, informando sobre a escolha tecnológica de um produtor que instalou duas unidades de produção: uma “... para produtos de revestimentos cerâmicos de alto valor agregado pelo processo conhecido como via úmida" e outra “... para produção de revestimentos cerâmicos de menor valor agregado pelo processo via seca".

Experimentos realizados pelo Centro Cerâmico de Bologna (NASSETTI, PALMONARI, 1997) tornaram possível uma comparação precisa entre massas preparadas pelos processos via seca e via úmida, partindo da mesma composição, para a produção de peças de monoqueima de base vermelha. Os resultados ressaltam que as massas granuladas (processo a seco) possuem menor retração de queima, maior absorção de água e menor resistência mecânica. Percebe-se, então, 
que as massas preparadas com o processo via úmida possuem melhores características tecnológicas, quando todas as condições são iguais.

Araújo, Romachelli e Martins (2001, p. 29) evidenciam que "os produtos confeccionados por via úmida tendem a apresentar maior constância de qualidade...".

Outra grande diferenciação da tecnologia brasileira, quando comparada com a européia, aparece no grau de automação das linhas. Como antes ressaltado, no Brasil não acontece a estocagem, de automação integral, antes e após a fase de queima. 


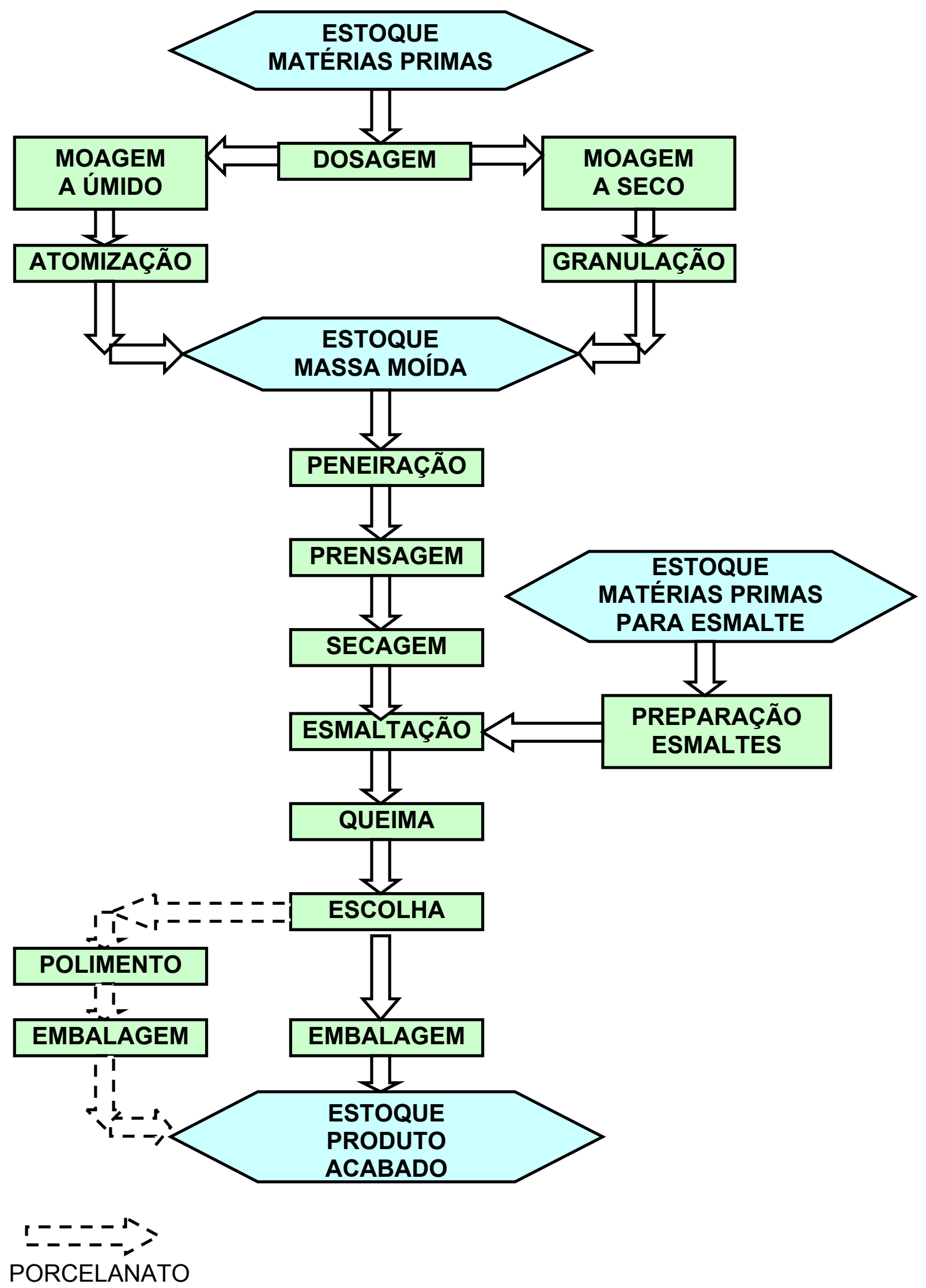

Figura 4 - Fluxograma do processo de produção de monoqueima no Brasil 


\subsection{Aspectos ambientais}

Com relação aos aspectos ambientais, novamente se observa uma "gritante" diferença entre as realidades dos dois países. Na Itália, a existência de limites rígidos das emissões de efluentes líquidos e atmosféricos, a constante fiscalização dos Órgãos de controle, a efetiva aplicação de penalidades de caráter pecuniário e penal e caso os limites impostos sejam ultrapassados, mesmo que temporariamente, a recente necessidade de coordenação das políticas comunitárias da União Européia obrigam os fabricantes a manter um rigoroso controle sobre características poluentes das instalações e o impacto ambiental. A título de exemplo, em 1998 verificou-se que $90 \%$ das empresas tratavam e reciclavam as águas de processo, limitando o consumo efetivo a $40 \%$ das necessidades; todas as plantas eram dotadas de equipamentos para depuração das emissões gasosas, respeitando integralmente os limites impostos pela legislação. Do ponto de vista energético, as empresas consumiam, sempre em 1998, as mesmas quantidades de 1977, com uma produção mais que dobrada (ASSOPIASTRELLE, 1998). Todos estes resultados são atribuídos à inovação tecnológica e à constante modernização das plantas de produção. Nesta área deve ser também salientada a constante ação da Associação de setor (Assopiastrelle), que muito participa da divulgação de uma cultura ambientalista entre os empresários, fornecendo cursos, informações, realizando estudos e participando ativamente da definição de normas específicas e até negociando a definição de leis com as entidades governamentais.

No Brasil, este aspecto ainda não foi abordado com a necessária seriedade, faltando parâmetros técnicos claros para os limites de emissão, fiscalização eficaz e diretrizes para planos de desenvolvimento ambiental.

\subsection{Aspectos econômicos}

A crescente concorrência interna e internacional pressionou, ao longo dos anos, os ceramistas italianos a realizar produtos de valor agregado cada vez maior e com 
um conteúdo crescente de inovação, como o grés porcelanato, cuja participação, atualmente, ultrapassa $65 \%$ da composição do mix total da produção e cresce constantemente. As características técnicas do grés porcelanato exigem matérias primas de altíssima qualidade, principalmente do ponto de vista da pureza, não totalmente disponíveis na Itália, obrigando os produtores a importar uma percentagem preponderante do volume total de materiais (>60\%).

O Brasil, pelo contrário, não é obrigado a importar matérias primas, seja pela grande disponibilidade de matérias primas nacionais de alta qualidade, seja pela menor exigência de qualidade, em consideração do padrão do mix de produtos que o mercado nacional exige.

Do ponto de vista de consumo energético, a Itália alcançou níveis de eficiência altíssimos, investindo em isolamento térmico, recuperação de calor e co-geração; atualmente a co-geração é utilizada em mais de $35 \%$ das empresas e o consumo específico de energia térmica desceu a quase $2,5 \mathrm{Nm}^{3}$ de $\mathrm{GN}$ (gás natural) por $\mathrm{m}^{2}$ de piso produzido. Dados históricos (ASSOPIASTRELLE, 2007) indicam que, de 1978 até 1998, a produção dobrou e o consumo energético permaneceu constante.

No Brasil, a co-geração ainda não entrou no processo e os consumos térmicos específicos se atestam em valores maiores, estima-se acima de $3,5 \mathrm{Nm}^{3} \mathrm{GN} / \mathrm{m}^{2}$ no caso das plantas de monoqueima mais modernas, e próximo de $5 \mathrm{Nm}^{3} \mathrm{GN} / \mathrm{m}^{2}$ para a biqueima (BORDIGNON, KAMINSKI, 2007).

Com referência à mão de obra, vale salientar que a capacitação técnica dos profissionais é similar nos dois países.

A título de exemplo, as tabelas 17 e 18 resumem a composição dos custos dos produtos italianos. No Brasil não é publicado oficialmente um levantamento de custos similar.

Tabela 17 - Custos totais de fabricação no mercado italiano

\begin{tabular}{|l|c|c|}
\hline Itens de custo & Euros $/ \mathbf{m}^{2}$ & Participação \% \\
\hline Produção & 6,94 & $70,54 \%$ \\
\hline Comerciais & 2,09 & $21,12 \%$ \\
\hline Administrativos e Financeiros & 0,82 & $8,34 \%$ \\
\hline Custo médio total & 9,86 & $100,00 \%$ \\
\hline
\end{tabular}

(Adaptado de Confindustria Cerâmica, 2007) 
Tabela 18 - Composição de custos de produção do mercado italiano

\begin{tabular}{|l|c|c|}
\hline Itens de custo & Euros $/ \mathbf{m}^{2}$ & Participação \% \\
\hline Matérias primas suporte & 1,26 & $18,08 \%$ \\
\hline Esmaltes e cores & 0,64 & $9,18 \%$ \\
\hline Energia elétrica & 0,38 & $5,46 \%$ \\
\hline Energia térmica & 0,72 & $10,39 \%$ \\
\hline Materiais consumíveis - manutenção & 0,66 & $9,48 \%$ \\
\hline Embalagens & 0,29 & $4,18 \%$ \\
\hline Mão de obra direta (produção) & 1,63 & $23,52 \%$ \\
\hline Acessórios e manufaturas externas & 0,88 & $12,66 \%$ \\
\hline Depreciação & 0,49 & $7,04 \%$ \\
\hline Custo médio total & 6,94 & $100,00 \%$ \\
\hline
\end{tabular}

(Adaptado de Confindustria Cerâmica, 2007)

\subsection{Síntese}

Em síntese, a comparação da tecnologia de produção na Itália e no Brasil se reduz a dois pontos importantes: no Brasil é amplamente difundido o uso de massa preparada com processo a seco e falta a automação pré/pós queima. Em ambos os casos, as conseqüências sobre a qualidade do produto acabado são indiscutíveis e o reflexo sobre o preço de produto já foi amplamente descrito e explicado.

Um breve comentário merece ser feito a respeito da biqueima, que na Itália ainda é responsável por um volume não insignificante e restrito a azulejos com decoração altamente sofisticada e de alto custo. Estima-se que, no Brasil, esta tecnologia é responsável por uma produção comparável à italiana e próxima a $7 \%$ do total. $\mathrm{A}$ diferença marcante é que a fabricação nacional é obsoleta. A tendência da produção é decrescente com a progressiva desativação das linhas de produção a favor de novas instalações de monoqueima.

A tabela 19 resume algumas características tecnológicas da produção na Itália e no Brasil. 
Tabela 19 - Resumo das características tecnológicas

\begin{tabular}{|l|l|c|c|}
\hline \multicolumn{2}{|l|}{ PARÂMETRO } & ITÁLIA & BRASIL \\
\hline Tipologia de produção & Monoqueima & $86,7 \%$ & $90 \%{ }^{(1)}$ \\
\cline { 2 - 4 } & Biqueima & $8,8 \%$ & $<7,0^{(1)}$ \\
\hline Tipologia de produto & Convencional & $35 \%$ & $97 \%$ \\
\cline { 2 - 4 } & Grés porcelanato & $65 \%$ & $3 \%$ \\
\hline Processo de produção & Massa úmida & $99 \%^{(1)}$ & $42,4 \%$ \\
\cline { 2 - 4 } & Massa seca & $1 \%{ }^{(1)}$ & $57,6 \%$ \\
\hline Automação de linha & Estoque pré/pós queima & $100 \%^{(1)}$ & $0 \%{ }^{(1)}$ \\
\hline
\end{tabular}

(1): dados estimados pelo autor, na ausência de dados oficiais.

A Tabela 19 procura mostrar, de forma resumida, os aspectos destacados na comparação entre os mercados analisados, focando os fatores tecnológicos.

A distribuição por tipologia de produção (monoqueima-biqueima) é perfeitamente comparável em termos de volume de produção, mas diverge substancialmente analisando as características técnicas do produto e das linhas de produção. $\mathrm{Na}$ Itália, a produção é limitada a produtos de alto valor agregado e realizada com equipamentos modernos, ao passo que no Brasil a biqueima é resíduo de produções tradicionais de baixo valor manufaturadas em plantas obsoletas e de altos custos.

A análise da tipologia de produto espelha a característica do mercado italiano, de busca de excelência, privilegiando uma abordagem sofisticada de pesquisa, inovação e qualidade do produto, o grés porcelanato, e alto investimento e profissionalização em tecnologia e sistemas de gestão. Esta tendência é confirmada pela distribuição do processo de produção. Na Itália, a escolha do processo a úmido está consolidada e é indiscutível, lembrando que a pequena percentagem de utilização do processo a seco é relacionada com produtos especiais. No Brasil, a escolha da tecnologia a seco é determinada por razões de economia de processo e orientada à fabricação de produtos de qualidade inferior. Confirmando o acima comentado, a adoção das características de automação de linha, na Itália, visam a sustentar de forma coerente a obtenção da máxima qualidade do produto, juntamente com a minimização dos custos de produção. 


\section{ANÁLISE COMPARATIVA E RECOMENDAÇÕES}

No presente capítulo são recolhidas as principais comparações entre as realidades brasileira e italiana, focando a relação entre os diferentes aspectos analisados ao longo do trabalho, incluindo normas, mercado, tecnologia e estratégia, procurando identificar os reflexos sobre a qualidade do produto e as implicações de mercado.

As considerações conclusivas da análise realizada permitem a geração de algumas recomendações, consideradas essenciais para a sobrevivência e a recuperação do setor, especificando os atores mais influentes a que estas recomendações se destinam.

\subsection{Análise comparativa}

A situação normativa no Brasil pode ser considerada satisfatória e plenamente coerente com os maiores competidores do mercado, quando analisada do ponto de vista estritamente técnico. Aparece, todavia, fortemente inadequada se avaliada sob o enfoque técnico-comercial, já que a certificação de qualidade de sistema ISO 9000 é considerada atualmente exigência mínima e não mais suficiente a sustentar uma imagem de alta qualidade da produção. A Tabela 20 permite visualizar a situação atual nos dois países.

Tabela 20 - Situação normativa atual

\begin{tabular}{|c|c|c|}
\hline \multirow[t]{2}{*}{ OBJETIVO } & \multicolumn{2}{|c|}{ SITUAÇÃO } \\
\hline & ITÁLIA & BRASIL \\
\hline $\begin{array}{l}\text { Norma técnica (Classificação, especificação de produto e } \\
\text { metodologia de teste) }\end{array}$ & \multicolumn{2}{|c|}{ Normas harmonizadas } \\
\hline Qualidade de sistema & \multicolumn{2}{|c|}{ ISO 9000} \\
\hline Certificação de excelência ambiental (ISO 14000) & Ecolabel & - \\
\hline $\begin{array}{l}\text { Qualidade do produto } \\
\text { Denominação de Origem } \\
\text { Segurança }\end{array}$ & $\begin{array}{l}\text { Certiquality } \\
\text { Cerâmica di qualitá } \\
\text { CE - Keymark }\end{array}$ & $\begin{array}{l}- \\
- \\
-\end{array}$ \\
\hline
\end{tabular}


No âmbito do presente trabalho, da comparação entre Itália e Brasil, observa-se que a Itália gerou as próprias normas técnicas (UNI), que foram mundialmente aceitas com a integração nas normas ISO; O Brasil publicou as normas ABNT, perfeitamente harmonizadas com as correspondentes ISO.

Em ambos os países um número relevante de produtores obtiveram a certificação do sistema de qualidade, conforme as normas ISO 9000.

Muitos fabricantes italianos responderam com rapidez à publicação da norma ISO 14000 de gerenciamento ambiental, coordenados e apoiados pela associação de categoria, solicitando e obtendo a certificação Ecolabel de excelência ambiental. A UNI gerou uma certificação de produto, o selo Certiquality. A União Européia exige também uma certificação de conformidade às normas de segurança para produtos destinados à construção civil, o Keymark.

$\mathrm{Na}$ ótica de preservar a liderança em termos de qualidade, a Assopiastrelle solicitou, com sucesso, a criação e um selo de Denominação de Origem, o "Ceramica di Qualitá".

A comparação entre os mercados europeu e brasileiro é extremamente complexa e baseia-se em inúmeros fatores históricos, econômicos e sociais. A tabela 21 apresenta os principais dados de mercado.

Tabela 21 - Principais dados de mercado

\begin{tabular}{|l|l|c|c|}
\hline PARÂMETRO & UNIDADE & ITÁLIA & BRASIL \\
\hline Produção total & {$\left[\mathrm{Mm}^{2}\right]$} & 589 & 566 \\
\hline Venda total & {$\left[\mathrm{Mm}^{2}\right]$} & 601 & 574 \\
\hline Venda no mercado nacional & {$\left[\mathrm{Mm}^{2}\right]$} & 188 & 448 \\
\hline Exportação & {$\left[\mathrm{Mm}^{2}\right]$} & 413 & 126 \\
\hline Preço médio do vendido & $\mathrm{US} \$ / \mathrm{m}^{2}$ & 11,0 & 2,72 \\
\hline
\end{tabular}

Base: 2004.

A produção total dos dois países é muito próxima. A Itália exporta $70 \%$ da produção, dirigida aos mercados europeu e norte-americano. A liderança comercial deste país é sustentada por grandes investimentos em pesquisa de materiais e produtos e pelo constante aprimoramento da qualidade e da eficiência do processo de produção. Os fabricantes brasileiros se desenvolveram num grande mercado 
consumidor, focando a distribuição local que exige material de baixo custo, podendo utilizar matérias primas locais. Desfrutando de alguns períodos de política de proteção, cresceram num ambiente de pouca concorrência e sem necessidade de desenvolvimento extremo. Quase $80 \%$ da produção é distribuída no mercado interno. A exportação é dispersa, privilegiando, todavia, o mercado norte-americano, no qual consegue um valor dos produtos significativamente inferior ao dos concorrentes. A desvalorização é devida à tendência de abastecer compradores externos em busca de preços baixos, gerando vendas de oportunidade circunstancial e um mercado volátil. Os fabricantes italianos, operando num mercado muito competitivo e com custos crescentes, foram obrigados a desenvolver continuamente produtos mais sofisticados e de alto valor agregado.

O parâmetro que mais claramente evidencia as diferenças entre os dois mercados é o preço médio do produto vendido, verificando que a razão entre os dois valores é próxima a 5. A Itália consegue o maior preço de produto no mundo, ao passo que o Brasil realiza um preço entre os menores do mercado mundial, comparável apenas ao valor obtido por países não representativos, sem a estrutura produtiva e a tradição do quarto produtor mundial.

O resultado é, atualmente, uma forte vulnerabilidade em função da obsolescência das linhas de produção e das estruturas organizativas e comerciais.

Comparando as duas realidades no campo tecnológico, o Brasil apresenta um parque industrial obsoleto; os investimentos permanecem num patamar baixíssimo e limitados a novas instalações.

A Tabela 22 resume as características tecnológicas salientes.

Tabela 22 - Principais características tecnológicas

\begin{tabular}{|l|l|c|c|}
\hline PARÂMETRO & ITÁLIA & BRASIL \\
\hline Tipologia de produto & Convencional & $35 \%$ & $97 \%$ \\
\cline { 2 - 4 } & Grés porcelanato & $65 \%$ & $3 \%$ \\
\hline Processo de produção & Massa úmida & $99 \%$ & $42,4 \%$ \\
\cline { 2 - 4 } & Massa seca & $1 \%$ & $57,6 \%$ \\
\hline Automação de linha & Estoque pré/pós queima & $100 \%$ & $0 \%$ \\
\hline
\end{tabular}


O custo de capital limita novos investimentos para aumentar a eficiência energética e o controle ambiental. Novas linhas de produção continuam sendo implantadas sem o cuidado de melhorar automação, eficiência térmica e emissões de poluentes. A produção de grés porcelanato, no Brasil, não alcança $3 \%$ do total, permanecendo o foco no produto tradicional. Os produtores nacionais são divididos com respeito à escolha do processo, parte produzindo a úmido, parte a seco.

A Itália tem estimulado a busca da excelência, com altas taxas de investimento destinado a tecnologia, automação e pesquisa. Para a obtenção de produtos da máxima qualidade com custos controlados, a opção geral foi a massa atomizada, obtida por via úmida, realizando materiais de alto valor agregado, que atualmente representam mais de $65 \%$ do total produzido.

A forte preocupação com a preservação ambiental, na Europa, se reflete nas características das instalações produtivas dos ceramistas italianos, dotadas de sistemas de filtragem das emissões gasosas, de reciclagem das águas de processo, de recuperação de calor e, cada vez mais, de cogeração. No Brasil faltam dados estatísticos a respeito das instalações de proteção ambiental. Pela experiência do autor, várias empresas adotam algum sistema, embora parcial, de tratamento das águas de processo, pouquíssimas apresentam tratamento de efluentes gasosos, limitadamente a algumas fases do processo, e o descuido com o fator energético é generalizado.

Com relação aos aspectos econômicos, tratados no item 4.5., vale evidenciar que a Itália é fortemente penalizada pela necessidade de importar grande quantidade de matéria prima, fato que encarece sensivelmente o produto. Os custos energéticos, na Itália, são cuidadosamente controlados e a cogeração é uma prática em forte expansão. No Brasil, as matérias primas são integralmente nacionais, a recuperação de calor não é utilizada e nenhuma empresa utiliza sistemas de cogeração.

Nesta área, também, o Brasil carece de dados e informações oficiais e confiáveis.

Para completar a comparação, examinaram-se os aspectos estratégicos de gestão empresarial e da produção.

O forte crescimento profissional dos fabricantes italianos levou, nos últimos anos, ao desenvolvimento de sistemas de gestão que prezam o uso cuidadoso de um alto volume de dados e indicadores técnico-econômicos confiáveis. Estas informações, devidamente compartilhadas, permitem uma participação pró-ativa da associação de setor (Assopiastrelle), que publica e executa estudos, análises e projeções, 
determinando linhas-guia e colaborando de forma sinérgica com o desenvolvimento do setor, disponibilizando um quadro claro da situação econômica e das tendências de mercado, sugerindo o desenvolvimento de novos produtos e de políticas de vendas, de marketing e ambientais.

Totalmente diferente é a situação nacional. As associações locais não conseguem realizar uma participação ativa na vida empresarial do setor. A falta de sistemas modernos de gestão e de uma cultura empresarial avançada impede a necessária elaboração e disponibilização, por parte dos fabricantes, de dados e informações preciosas para a geração e manutenção de banco de dados do setor. Conseqüentemente, inviabiliza-se a elaboração de estudos ou análises setoriais, a criação de observatórios e de todas as outras atividades que normalmente competem às associações de categoria. A falta de difusão de informações é comumente justificada com a necessidade de sigilo a respeito de dados estratégicos. Esta motivação, objetivamente, confirma a carência de capacitação e profissionalismo dos gestores e, provavelmente, é utilizada para ocultar algumas práticas ilegais de informalidade.

\subsection{Recomendações}

Com base nas pesquisas e análises efetuadas no presente trabalho, é perceptível a situação de latente fragilidade do setor cerâmico nacional. A velocidade de desenvolvimento do ambiente econômico mundial gera uma situação de alto risco que deve ser entendida e interpretada rapidamente.

É evidente a imediata necessidade de reestruturação da produção cerâmica no Brasil, envolvendo cada empresa atuante e o setor como um todo.

Algumas recomendações podem ser formuladas, juntamente com a definição dos atores principais aos quais são destinadas. Vale evidenciar que, para manter objetividade e foco, serão relatadas apenas as sugestões mais importantes e urgentes.

É possível restringir a apenas três os atores importantes, que mais podem influenciar o setor cerâmico nacional, sendo estes o Governo, as Empresas e as Associações de categoria. 
Do ponto de vista normativo, a situação européia pode servir de inspiração para estruturar algum tipo de regulamentação ambiental, baseada na definição de políticas ambientais e estratégias energéticas de alcance nacional.

Seguidamente, as entidades responsáveis para a normatização definem as certificações relativas. Os atores envolvidos são o Governo e as Associações dos ceramistas, pois é impensável a regulamentação de um setor produtivo sem a determinante participação dos representantes das indústrias.

As estratégias comerciais devem ser, ao menos parcialmente, revistas, destinando uma percentagem maior da produção à exportação e procurando estruturar redes próprias de distribuição no exterior, com revendas, agentes ou representantes. Para conter os custos, às vezes proibitivos, de criação de uma estrutura comercial própria para cada empresa, devem ser exploradas formas de associações ou consórcios de distribuição, concentrando-se num número menor de mercados e privilegiando aqueles pouco explorados ou de baixo interesse para os maiores competidores. Esta atuação envolve principalmente as empresas, coordenadas pelas Associações.

Do ponto de vista da tecnologia de produção, é necessário realizar altos investimentos na tecnologia de processo, modernizando as linhas de produção e dotando as novas instalações de sistemas avançados de controle energético (isolamento e recuperação de calor) e ambiental. Fundamental é também manter o foco na melhoria e integração da automação de linha. Uma parcela dos investimentos deve, também, ser destinada à pesquisa; em ambos os casos procurando aumento da qualidade dos produtos. Chiva e Alegre (2007), numa recente pesquisa entre empresas cerâmicas na Itália e na Espanha, destacam a importância da pesquisa em tecnologia e design para realizar produtos de alto valor agregado e de alta qualidade, fundamentais para sustentar a imagem da marca e as lideranças no mercado mundial.

Para sustentar a necessidade de investimentos em tecnologia, cita-se Grahl (2004), que descreve recentes investimentos realizados no setor cerâmico nos EUA. O estudo confirma que, definindo corretamente os mercados alvos, utilizando processos e matérias primas selecionadas e de alta qualidade, instalando equipamentos de última geração e realizando sólidas parcerias com órgãos oficiais e profissionais do setor, é possível ganhar mercado e realizar atividades lucrativas mesmo em áreas hoje consideradas críticas ou não favorecidas, em considerações 
dos custos de mão de obra, dos rígidos limites legais e ambientais e da concorrência de outros países que dominam o mercado mundial.

Quando possível, é importante analisar as experiências européias, principalmente na Espanha, de criação de consórcios de produção de massa atomizada. Trata-se de centros de produção de alta potencialidade, gerenciados de forma cooperativa por vários ceramistas e dimensionados para produzir a massa necessária a todos os associados. Tais estruturas permitem grandes economias de escala, custos baixos, aumento da qualidade das matérias primas e redução, para cada fabricante, da necessidade de investimentos, gerenciamentos e manutenção de todo o setor de preparação de massa. O projeto destas plantas prevê a presença de grandes equipamentos de cogeração, que, dependendo do dimensionamento, pode tornar auto-suficientes todos os consorciados, no consumo de energia elétrica. É supérfluo comentar economias e ganhos em termos de autonomia e estratégia.

$\mathrm{Na}$ realidade brasileira, este tipo de aplicação seria especialmente adequado para a região de Santa Gertrudes, em consideração da grande semelhança entre os produtos, da matéria prima altamente homogênea, do alto número e da proximidade dos fabricantes da região.

O aspecto tecnológico envolve principalmente as empresas e, considerando o volume de investimento e as resultantes energéticas, o Governo. Este deve participar com planos de incentivos, prevendo linhas de financiamento específicas e desconto ou redução de impostos para os investidores. Vale lembrar que a indústria cerâmica gera um alto volume de negócios dentro do setor industrial; em 2004, o setor cerâmico representava mais de 25.000 empregos diretos e 250.000 indiretos (ANFACER, 2006).

Por último, o aspecto estratégico. Nessa área os principais responsáveis são as empresas e as Associações de categoria.

Devem ser desenvolvidos planos estratégicos, de médio e longo prazo, com cuidadosa programação em termos de investimentos para novas tecnologias, renovação de parque industrial, profissionalização e qualificação dos recursos humanos (desde a alta direção até o pessoal operativo), realizações de parcerias reais e conscientes com Universidades, Associações de categoria, Centros de pesquisa, fornecedores e canais de distribuição profissionais.

Outro aspecto que se torna de fundamental importância para que o Brasil recupere competitividade é disponibilizar e gerenciar dados técnicos, econômicos e 
financeiros confiáveis, com o objetivo de aprofundar análises e comparações entre as empresas nacionais e outras realidades mais desenvolvidas (Itália e Espanha), otimizando a pesquisa, fomentando práticas de benchmarking e aproveitando as experiências já realizadas nestes países.

Uma participação construtiva de ANFACER e ASPACER seria extremamente saudável para poder alcançar o desenvolvimento sustentável do mundialmente importante setor cerâmico brasileiro.

Uma outra possibilidade que facilitaria $\mathrm{o}$ processo de recuperação $\mathrm{e}$ desenvolvimento do setor é representada pela fusão das duas principais associações de categoria, a ANFACER e a ASPACER. A presença simultânea e paralela de duas organizações setoriais, com os mesmos objetivos e funções, reduz a eficácia de qualquer ação em prol dos empresários nacionais. A existência de dois pólos de produção de cerâmica não justifica a criação de associações separadas e independentes já que interesses, mercados de atuação, problemáticas industriais, comerciais, econômicas, ambientais e tecnológicas são os mesmos para todos os produtores. A união das associações representaria um forte ganho em eficiência e eficácia, podendo desfrutar a acumulação sinérgica das competências de cada entidade, com conseqüências positivas em termos de credibilidade e força de negociação.

A Tabela 23 resume e visualiza as áreas de atuação e os principais atores envolvidos.

Tabela 23 - Matriz de presença de atores e áreas de atuação

\begin{tabular}{|l|c|c|c|}
\hline Áreas de atuação & GOVERNO & EMPRESAS & ASSOCIAÇõES \\
\hline NORMAS & $\mathbf{X}$ & & $\mathbf{X}$ \\
\hline MERCADO & & $\mathbf{X}$ & $\mathbf{X}$ \\
\hline TECNOLOGIA & $\mathbf{X}$ & $\mathbf{X}$ & $\mathbf{X}$ \\
\hline ESTRATÉGIA & & $\mathbf{X}$ & \\
\hline
\end{tabular}




\section{CONCLUSÕES}

A proposta do presente trabalho nasce da observação de diferenças estruturais entre os mercados cerâmicos da Itália, líder absoluto em termos de qualidade e preços, e do Brasil, $4^{\circ}$ produtor, que apresenta crescente vulnerabilidade.

O objetivo da Dissertação é compreender as causas, verificar sua persistência, analisar as conseqüências sobre mercado e produção e evidenciar a necessidade de reestruturação do setor; o foco de análise são os aspectos normativo, de mercado, tecnológico e estratégico.

O estudo comparativo da norma vigente verifica a equivalência entre os dois países do ponto de vista técnico, frente a um forte desnível nos aspectos comerciais relacionados com a citada norma.

Os dados de mercado permitem identificar uma situação aparentemente similar em termos de volume de produção, porém amplamente diferenciada do ponto de vista qualitativo, evidenciando uma preponderante vulnerabilidade da produção nacional.

A verificação da situação histórica e da atual, do ponto de vista tecnológico, aponta para poucas causas geradoras da diversidade que, todavia, permanece efetiva, colocando o mercado brasileiro numa posição de risco latente à frente da evolução do panorama mundial.

A comparação das estratégias empresariais adotadas nos dois países aponta para a necessidade de reformulação e modernização das empresas brasileiras, passando por um processo de reciclagem dos atuais gerentes, objetivando técnicas de gestão mais consistentes e participativas.

O exame da ampla bibliografia nacional e internacional consultada, juntamente a considerações críticas, sustenta a demonstração da necessidade urgente de uma profunda reestruturação deste importante setor econômico nacional, com o objetivo de recuperar uma competitividade perdida.

Os caminhos para esta recuperação passam por uma renovação tecnológica e de gestão estratégica. A síntese do trabalho apresenta uma breve lista de recomendações que poderiam iniciar, de forma eficaz, o processo de renovação. 
O trabalho pode ser considerado relevante, pois representa uma análise crítica de um setor econômico aparentemente estável, apontando para fraquezas e situações de riscos.

A partir desta dissertação é esperado o desenvolvimento de outros trabalhos acadêmicos; os temas principais a serem abordados derivam da lista de recomendações do Capítulo 5, envolvendo prospecções estatísticas, estudos de estratégia empresarial, propostas de investimentos, análises de caráter técnicoeconômico.

Possíveis objetivos serão:

1. propostas de implementação de novas tecnologias de processo, focando a extensão da automação de linha, avaliando as condições econômicas e financeiras do setor;

2. desenvolvimento de estratégias de geração de produtos com maior valor agregado, focando realização de pesquisas sobre novos materiais e tecnologias;

3. projetos para a realização de consórcios para a produção centralizada de massa atomizada em alguns pólos de produção, sustentadas por estudos de harmonização de exigências e conflitos entre os participantes, projetos e análise de viabilidade;

4. pesquisas, no mercado produtor, para avaliar o nível de estratégias atualmente implementadas e para verificar a adequação às exigências futuras de internacionalização;

5. análise de atuação das Associações nacionais de categoria e eventuais propostas de desenvolvimento de estratégias de setor, baseadas na comparação dos casos de sucesso das Associações européias;

6. pesquisas e análises da situação ambiental e energética, com propostas de adequação aos padrões internacionais. 


\section{REFERÊNCIAS}

AMERICAN NATIONAL STANDARD INSTITUTE. 4662-2003: Ceramic tiles Definitions, classification, characteristics and marking. 2003. Disponível em $<$ www.ansi.org>, acesso em 27/04/06.

4459: Methods of sampling and testing ceramic tiles. 1997-1999.

Disponível em <www.ansi.org>, acesso em 27/04/06.

ANFACER. Censo. São Paulo: 2004. Disponível em: <http://www.anfacer.org.br>. Acesso em 10 fev. 2006.

Análise setorial 2003. São Paulo: 2004. Disponível em:

<http://www.anfacer.org.br>. Acesso em 10 fev. 2006.

ARAÚJO, A.; ROMACHELLI, J. C.; MARTINS, M. Análise crítica do setor de revestimento cerâmico no Brasil parte I: histórico recente. Cerâmica Industrial, São Paulo, v. 6, n. 4, p. 29-34, jul./ago. 2001.

Análise crítica do setor de revestimento cerâmico no Brasil parte II: crescimento da capacidade produtiva. Cerâmica Industrial, São Paulo, v. 6, n. 5, p. 7-14, set./out. 2001.

ASSOCIAÇÃO BRASILEIRA DE NORMAS TÉCNICAS. NBR 13816: Placas cerâmicas para revestimento - Terminologia. São Paulo: ABNT, 1997.

NBR 13817: Placas cerâmicas para revestimento - Classificação. São Paulo: ABNT, 1997.

NBR 13818: Placas cerâmicas para revestimento - Especificação e métodos de ensaio. São Paulo: ABNT, 1997.

NBR 15463: Placas cerâmicas para revestimento - Porcelanato. São Paulo: ABNT, 2007.

ASSOPIASTRELLE. Marchio CE e piastrelle di cerâmica. Linee guida per la marcatura CE per le piastrelle di cerâmica. Sassuolo: Assopiastrelle, 2004. 
ASSOPIASTRELLE, SNAM. Piastrelle di cerâmica e refrattari. Rapporto Integrato 1998 - Ambiente, energia, sicurezza - salute, qualitá.Sassuolo:Assopiastrelle, 1998.

Settori e aziende. Modena, s.d. Disponível em:

<http://www.assopiastrelle.it>. Acesso em 07 de fevereiro de 2006.

Consumi energetici. Modena, s.d. Disponível em:

<http://www.assopiastrelle.it>. Acesso em 20 de junho de 2007.

BELTRAME, E. Tecnologia e padrão de concorrência da indústria de revestimentos cerâmicos de Santa Catarina. 1998, 130 p. Dissertação (Mestrado) - UFSC, Florianópolis, 1998.

BIFFI, G. Defeitos de fabricação das placas cerâmicas. Rio Claro: Faenza Editrice do Brasil, 2000.

BORDIGNON, F. Instalação de planta piloto no laboratório de assistência técnica de um colorifício cerâmico. 2004. 66 p. Monografia MBA - EPUSP-PECE. São Paulo, ago.2004.

BORDIGNON, F; KAMINSKI, P. C. Technical and economic evaluation of an installation project of a pilot plant in the technical assistance laboratory of a ceramic glaze producer. In: International Congress of Mechanical Engineering, 18 ${ }^{\text {th }}$., 2005: Ouro Preto. COBEM 2005 - Proceedings. Rio de Janeiro: ABCM, 2005.

Planta piloto no colorifício cerâmico. Cerâmica Informação, Rio Claro, n. 45, p. 43-48, mar./abr. 2006.

Comparação da metodologia de produção de monoqueima na Itália e no Brasil. In: Congresso Brasileiro de Engenharia de Fabricação, 4., 2007: Águas de São Pedro. COBEF 2007 - Proceedings. Rio de Janeiro: ABCM, 2007.

BOSCHI, A. O. O Pólo de Santa Gertrudes e a Indústria Brasileira de revestimento cerâmico. Cerâmica Industrial, São Paulo, v. 9, n. 3, p. 7-12, mai./jun. 2004.

CENTRO CERAMICO DI BOLOGNA. The Italian ceramic tile dictionary. Sassuolo: Edizioni Edi.Cer., 1999. 
CERTIQUALITY S.r.I. - ISTITUTO DI CERTIFICAZIONE DELLA QUALITÁ.

Regolamento per la concessione e il mantenimento del diritto d'uso dei marchi di conformitá Certiquality-UNI e Certiquality-UNI/Keymark alla Norma UNI EN 14411 per le piastrelle di cerâmica. Milano: Certiquality, Doc 32 ed. 02, 2005.

CHIVA, R; ALEGRE, J. Linking design management skills and design function organization: An empirical study of Spain and Italian ceramic tile producers. Technovation (2007), doi/; 10.1016/j.tecnovation. 2007.05.015. Aceito para publicação.

CONFINDUSTRIA CERAMICA. Struttura dei costi e dinamiche tendenziali nelle diverse tipologie di piastelle di ceramica. Sassuolo: Confindustria ceramica, 2007.

GAMBULI, P. World trends in ceramic tile production. American Ceramic Society Bulletin, v. 80 n. 12 25-8 D, 2001.

GRAHL, C. Taking chances. Ceramic Industry, Troy, vol. 154, Iss. 3, mar. 2004.

GUIA GEOGRÁFICO. Mapas do Brasil. Disponível em: <www.brasilturismo.com/mapas.htm>; acesso em 28/11/2007.

INTERNATIONAL ORGANIZATION FOR STANDARDIZATION. Ceramic tiles Definitions, classifications, characteristics and marking - ISO 13006. Geneve, 1998. . Ceramic tiles - ISO 10545. Geneve, 1997.

JORNAL PÓLO CERÂMICO. Setor fecha 2005 com crescimento de $9,8 \%$. São Paulo, fevereiro 2006, p. 34.

MINISTÉRIO DA FAZENDA, BANCO CENTRAL DO BRASIL. Taxas de câmbio Cotações e boletins. Disponível em: <www.bc.gov.br>; acesso em 08/06/2006.

NASSETTI, G.; PALMONARI, C. Moagem fina a seco e granulação vs. moagem a úmido e atomização na preparação de massas de base vermelha para monoqueima rápida de pisos vidrados. Cerâmica Industrial, São Paulo, v. 2, n. 5/6, p. 11-15, set./dez. 1997. 
NOGUEIRA, E.; ALVES, A.G.; TORKOMIAN, A.L. Empresas de revestimento cerâmico e suas estratégias competitivas e de produção. Gestão e Produção, São Carlos, v. 8, n. 1, p. 84-99, abr. 2001.

OLIVEIRA, A.P. Tecnologia de fabricação de revestimento cerâmicos. Cerâmica Industrial, São Paulo, v. 5, n. 6, p. 37-47, nov./dez. 2001.

OLIVEIRA, M.L. de As exportações brasileiras de produtos cerâmicos para revestimento no período de 1980-2001. Cerâmica Industrial, São Paulo, v. 7, n. 5, p. 29-39, set./out. 2002.

PALMONARI, C.; TIMELLINI, G. Guida alla scelta delle piastrelle ceramiche. Sassuolo: Edizioni Edi.Cer., 2000.

Guida alle norme sulla qualitá e sulle caratteristiche delle piastrelle di ceramica italiane. Sassuolo: Edizioni Edi.Cer., 2000.

PALMONARI, C.; CARANI, G. Le piastrelle di cerâmica sotto controllo. Bologna: Litosei, 2005.

PASCHOAL, J.O. Ciência \& Tecnologia \& Inovação. Cerâmica Informação, Rio Claro, n. 50, p. 8, jan./fev. 2007.

RENAU, R.G. Pastas y vidriados en la fabricación de pavimentos y revestimientos cerámicos. Castellon: Faenza Editrice lbérica, 1994.

RIBEIRO, J.A.; QUINTAL, C.A. Considerações logísticas e estratégicas que levaram a Incefra a optar pela instalação de duas novas empresas na Bahia. Cerâmica Industrial, São Paulo, v. 6, n. 3, p. 14-17, mai./jun. 2001.

SACMI. Floor tiles technology. Imola, s.d.. Disponível em: <http://www.sacmi.it>. Acesso em 01 de março de 2004.

Tecnologia cerâmica applicata. II ed. Vol 1. Imola: Editrice La Mandragora, 2003. 
SEZZI, G. Produção e consumo mundial de revestimentos cerâmicos. Cerâmica Industrial, São Paulo, v. 7, n. 5, p. 20-28, set./out. 2002.

VECCHI, G. Tecnologia ceramica illustrata. Faenza: Faenza Editrice, 1977.

VENTURI, V. Tecnologia ceramica - Le piastrelle. Faenza: Faenza Editrice, 1986. 